\title{
COMENTÁRIOS SOBRE AS UNIDADES DE TEMPO GEOLÓGICO: UMA ABORDAGEM ONOMATOLÓGICA
}

COMMENTS ON GEOLOGICAL TIME UNITS: AN ONOMATOLOGICAL APPROACH

\author{
REYNALDO CÍCERO DE TOLEDO \& MARIA DO SOCORRO SILVA PEREIRA LIPPI \\ Universidade Santo Amaro - UNISA, Campus Metrô Adolfo Pinheiro. Rua Isabel Schmidt, 349 - Santo Amaro, São Paulo - SP, \\ 04743-030. E-mail: rcd.toledo@gmail.com; sopeli4@gmail.com
}

\begin{abstract}
Resumo: Neste artigo objetivou-se destacar a contribuição de vários autores para o conhecimento e a nomenclatura das unidades geocronológicas. Revisou-se sucintamente a história da Geologia e da Paleontologia desde a Antiguidade Clássica até o século XIX, no qual houve as contribuições relevantes relacionadas às unidades de tempo geológico e seus respectivos nomes. Neste trabalho são fornecidas informações gerais a respeito dos eventos que ocorreram em cada um desses momentos da história geológica do planeta. Além disso, procurou-se realizar uma análise dos nomes dessas unidades, bem como de seus elementos de composição, mencionados por autores clássicos. Para isso, foram incluídas informações históricas, além das etimológicas e semânticas relacionadas aos termos considerados, por meio de consulta a dicionários linguísticos e especializados nas áreas geológicas, paleontológicas e biológicas, assim como de livros e artigos científicos pertinentes ao tema. Além disso, vários termos correlatos utilizados na literatura científica foram analisados sucintamente com a finalidade de se demonstrar que esses nomes clássicos e os seus derivados são ainda empregados na onomatologia científica dos dias atuais.
\end{abstract}

Palavras-chave: Unidades geocronológicas; Onomatologia; Tempo Geológico; Cronoestratigrafia

Abstract: This article aimed to highlight the contribution of several authors to the knowledge and nomenclature of geochronological units. The history of Geology and Paleontology from Classical Antiquity to the 19th century was briefly reviewed, in which there were relevant contributions related to geological time units and their respective names. This work provides general information about the events that occurred at each of these moments in the geological history of the planet. In addition, we tried to analyze the names of these units, as well as their compositional elements, mentioned by classical authors. In order to achieve this, historical information was included, in addition to etymological and semantic information related to the terms considered, by consulting linguistic and specialized dictionaries in geological, paleontological and biological areas, as well as books and scientific articles relevant to these studies. Furthermore, several related terms used in the scientific literature were briefly analyzed for the purpose of demonstrating that these classical names and their derivatives still take place in today's scientific onomatology. Keywords: Geochronological Units; Onomatology; Geological Time; Chronostratigraphy 


\section{INTRODUÇÃO}

Desde os tempos mais remotos, o relevo da superfície terrestre tem sido alvo da curiosidade dos povos das antigas civilizações que, de algum modo, procuraram explicar a existência de montanhas, vales, rios, mares, ilhas e terremotos (Minkoff 1983).

Os gregos da Antiguidade Clássica possuíam conceitos bem definidos acerca da origem da Terra e dos fenômenos geológicos. Em sua obra "Meteorologica", o filósofo e naturalista grego Aristóteles (384-322 a.C.) comentou a respeito de terremotos, alternância de continentes e oceanos e inundações do rio Nilo sem, no entanto, acrescentar novas contribuições ao que já se conhecia em relação a esses fenômenos (Zittel 1901). Teofrasto (368-284 a.C.), um discípulo de Aristóteles, destacou-se por seu trabalho na área de Botânica. Este naturalista grego escreveu, também, "Perì Líthon; De Lapidibus" (A Respeito de Rochas), uma obra que fornece informações a respeito de minerais e fósseis (Zittel 1901). No século I d.C., Plínio, o Velho (23-79 d.C.), em seu trabalho "História Natural", um tratado em 37 volumes, discutiu em dois de seus livros, alguns tópicos referentes à gemologia (do L. gemma, rebento, gema, pedra preciosa), mineralogia e cristalografia (Plínio 1906, HN, 36, 37).

$\mathrm{Na}$ Idade Média deve-se ressaltar a contribuição de importantes figuras do mundo oriental, entre as quais, Avicena, na Pérsia e Shen Kuo, na China. Avicena-Ibn Sina (981-1037), em seu trabalho enciclopédico, "The Book of Healing", dedicou alguns capítulos às ciências da Terra, discutindo vários tipos de fenômenos geológicos e meteorológicos. Entre os temas abordados, incluíam-se: formação de montanhas e minerais, origem dos terremotos, nuvens, chuvas e ventos (Al-Rawi 2002). Shen Kuo (1031-1095) observou alguns fenômenos geomorfológicos e paleontológicos, tais como erosão do solo, deposição de silte, plantas e animais petrificados. Ao constatar a ocorrência de fósseis de bivalves marinhos em montanhas, embora afastadas do mar, Kuo acreditava que devessem pertencer, no passado, a regiões marinhas (Sivin 2019).

Durante um longo período, era comum explicar o surgimento de montanhas, vales, mares e ilhas por atos de criação associados a divindades que os geravam por meio de eventos cataclísmicos (do G. kataklysmós, inundação, desaparição e ikós, relativo a). As teorias geológicas anteriores ao século XIX, em sua maioria, apoiavam o catastrofismo (do G. katastrophé, agitação, desastre e ismós, sufixo indicativo de condição, de resultado), uma teoria que explicava que a superfície da Terra fora modelada como resultado de cataclismas. Um dos mais ardorosos defensores de uma forma de catastrofismo foi Georges Cuvier (1769-1832). Este naturalista francês admitia que os estratos indicavam a ocorrência de eventos catastróficos que provocaram a destruição de todos os organismos. Como esses eventos deveriam ser localizados, as regiões onde eles ocorreram eram repovoadas por organismos sobreviventes que migrariam de outros locais. Segundo esta teoria, catástrofes sucessivas teriam dizimado componentes de todas as espécies viventes e extintas que coexistiam inicialmente (Bowler 2003). Nesse contexto, vários estudiosos acreditavam que deveria haver uma direção na história da vida, de origem sobrenatural. Segundo estes estudiosos, o aparecimento de seres vivos cada vez mais aperfeiçoados, representados em um estrato imediatamente superior, apontava, muito provavelmente, para o surgimento de uma criação sequencialmente mais perfeita (invertebrados, peixes, répteis e mamíferos), com os humanos representando o propósito fundamental dessa criação (Bowler 2003).

Entretanto, somente a partir do século XVII foram estabelecidas as bases da Estratigrafia (do L. strātum, coberta, camada e do G. graphé, escritura, descrição) e da Paleontologia (do G. palaiós, antigo, óntos, ser, lógos, descrição) pelo anatomista e geólogo dinamarquês Nicolaus Steno (1638- 
1686). Steno propôs a lei da superposição, baseada no fato de que ao se observar uma sequência de estratos, os mais antigos dispõem-se na parte de baixo e os mais recentes, na superfície dessa sequência. Posteriormente, o engenheiro inglês William Smith (1769-1839) foi quem colocou os fundamentos dessa lei em uso prático, propiciando o grande avanço nos conhecimentos da Paleontologia Estratigráfica (Minkoff 1983).

Foi, no entanto, o geólogo inglês James Hutton (1726-1797) quem estabeleceu as bases do Uniformitarismo (ou Uniformismo), o princípio que admite a invariabilidade das leis naturais com o tempo. Este princípio tem por base o fato de que os processos geológicos desenvolvem-se na atualidade, fundamentalmente, com as mesmas velocidades e intensidades em que operavam ao longo dos tempos geológicos de nosso planeta. O Uniformismo passou a ser uma teoria aceita somente quando o geólogo inglês Charles Lyell (1797-1875) adequou-a à sua forma moderna em seu trabalho "Principles of Geology", de 1830 (Minkoff 1983). Esta obra de Lyell foi, provavelmente, o mais importante livro de Geologia do século XIX, uma vez que deve ter estimulado o grande debate da Geologia nesse século. Esse debate envolvia os adeptos do catastrofismo, entre os quais, destacavam-se Georges Cuvier, Adam Sedgwick (1785-1853) e Louis Agassiz (1807-1873), que opunham suas ideias em relação às dos adeptos do uniformitarismo, defendido por James Hutton, Charles Lyell e Charles Darwin (18091882) (O'Hara 2018).

A Geologia (do G. gê, terra e lógos, estudo, descrição) tem por objetivo o estudo da estrutura física de nosso planeta (Geologia Física), bem como dos seus eventos históricos (Geologia Histórica). O termo geologia foi introduzido na literatura, em 1779 , pelo naturalista e geólogo suíço Horace-Bénédict de Saussure (1740-1799). O naturalista italiano Ulisse Aldrovandi (1522-1605) escreveu vários livros e manuscritos que contribuíram para a classificação de objetos geológicos e para o conhecimento dos processos de litificação e fossilização (Vai \& Cavazza 2006). Foi Aldrovandi, considerado o pai da Historia Natural, por Carolus Linnaeus (1707-1778) e Georges Leclerc de Buffon (1707-1788), quem empregou pela primeira vez o termo "giologia", em 1603. Este naturalista definiu o termo como a "ciência dos fósseis", com o objetivo de caracterizá-la como o estudo "das coisas extraídas da terra, desenterradas" (fossilia) (Bartorelli et al. 2015).

Um dos ramos das ciências geológicas, a Geocronologia (do G. gê, terra; khrónos, tempo; lógos, descrição) utiliza métodos de datação absoluta ou relativa com o objetivo de determinar intervalos de tempo em uma escala geológica. Rochas, fósseis e sedimentos podem ter suas idades determinadas por meio desses métodos. A geocronologia trata do tempo geológico, cuja medida quantitativa é objeto da geocronometria (do G. gê, terra; khrónos, tempo; métron, medida) (Allaby 2013). Os intervalos de tempo geológico denominam-se unidades geocronológicas, entre as quais incluem-se: os éons, as eras, os períodos e as épocas. O ramo da Estratigrafia cujo objetivo é o estudo dos estratos rochosos em relação ao conceito de tempo denomina-se Cronoestratigrafia (do G. khrónos; do L. strătum, camada; graphé, escrita, descrição) (Allaby 2013). As unidades cronoestratigráficas são as seguintes: Eonótema, Erátema, Sistema e Série (Houaiss \& Villar 2001, 2009).

$\mathrm{Na}$ Antiguidade há relatos referentes aos fósseis. Um dos primeiros, senão o primeiro filósofo a referir-se aos fósseis foi Xenófanes (c. 560 a.C. - c. 478 a.C.). Esse filósofo observou que em regiões montanhosas, na Ásia Menor, encontravam-se conchas de bivalves marinhos e admitiu que essas regiões deveriam ser cobertas por águas do mar, em algum tempo passado (Minkoff 1983). Xenófanes, portanto, interpretou essas conchas como restos de organismos que 
existiram em algum momento da história da Terra. Posteriormente, a escola de Aristóteles defendeu a ideia de que os fósseis poderiam ser produzidos espontaneamente na terra.

O artista e cientista italiano Leonardo da Vinci (1452-1519), quando trabalhava como engenheiro, no período de 1482 a 1499, tinha um bom conhecimento de rochas e fósseis do norte da Itália. Além disso, esse erudito interessou-se pelos processos de sedimentação e fossilização e, certamente, tinha a noção da lei da superposição, defendida posteriormente por Steno. Procurou explicar esses processos, após ter observado a ocorrência de conchas marinhas em regiões montanhosas (Melendez 1970 ). Da Vinci acreditava que os fósseis eram restos de seres vivos e, sua localização em regiões montanhosas davam apoio à ideia de que, durante certos períodos, as águas oceânicas tinham mudado suas posições em relação à terra firme (Stokes 1969).

Georges Cuvier, considerado o fundador da Paleontologia, com seus estudos de Anatomia Comparada, contribuiu muito para as ciências paleontológicas, a despeito de sua errônea explicação das extinções por processos cataclísmicos. Os conhecimentos sobre paleontologia que enfatizavam aspectos sistemáticos ou estratigráficos passaram a ser ampliados com a contribuição de outrasáreas das ciências biológicas. Obviamente, uma das maiores dessas contribuições ocorreu quando Charles Darwin desenvolveu seus trabalhos, uma vez que o estudo dos fósseis pôde ser realizado sob o ponto de vista evolutivo (Melendez 1970).

A Paleontologia, a ciência dos fósseis, tem como objetivo o conhecimento dos vestígios ou traços dos seres que viveram no passado, preservados nos estratos rochosos. Com o desenvolvimento dos vários campos científicos houve a necessidade de se estabelecer novos termos a fim de se definir estruturas ou processos. Isto também ocorreu nas áreas das ciências geológicas e paleontológicas contribuindo para o enriquecimento da nomenclatura dessas ciências. Uma grande diversidade de termos foi empregada para a designação dos vários eventos ocorridos ao longo do tempo geológico e alguns desses termos foram utilizados para denominar Eras e Períodos ${ }^{1}$.

Desse modo, podemos constatar que, fundamentalmente, desde o século XIX, diversos nomes têm sido atribuídos aos sedimentos em que os fósseis foram encontrados, bem como às idades em que viveram. O termo "palaeontologie" foi cunhado em 1822 pelo médico e naturalista Henri Marie de Blainville (1777-1850) que, em 1817, já havia criado o termo "paleozoologie" com o objetivo de designar o estudo dos fósseis de animais (Rudwick 2008).

É importante destacar que em todos os campos dos conhecimentos há nomes para designar os processos, as estruturas, os atributos e as ações. Isto não é diferente nas áreas das ciências geológicas e paleontológicas. Nestas áreas, os nomes referem-se a organismos, a tipos de rochas, de minerais, de processos, de formações e às idades. Na atualidade, existem inúmeros elementos de composição da terminologia das áreas geológicas e paleontológicas. Entre esses elementos podemos constatar alguns que se referem particularmente às Eras, Períodos e Épocas geológicas. Os nomes que designam esses períodos do tempo geológico podem ser estudados pela Onomatologia (do G. ónoma, atos, nome e lógos, estudo, descrição), um campo do conhecimento que tem por objetivo o estudo dos nomes. A Onomatologia Geológica trata dos nomes associados às áreas das ciências geológicas, analisando-os basicamente quanto à sua origem, seu significado e sua história.

Neste trabalho tem-se por objetivo fundamental relacionar os nomes dos Éons, Eras, Períodos e Épocas e analisá-los onomatologicamente, destacando-se aspectos etimológicos e semânticos; nesta análise, objetiva-se também, enfatizar os significantes e seus respectivos significados atuais na área das ciências geológicas e paleontológicas, os aspectos históricos a eles 
associados, destacando-se os autores mais diretamente envolvidos com a cunhagem desses nomes. Tem-se por objetivo específico analisar onomatologicamente termos criados por vários autores para a designação de formações, processos e organismos associados a essas unidades de tempo da história do planeta.

\section{MÉTODOS}

Para o desenvolvimento deste trabalho foram consultados:

Dicionários linguísticos para as informações etimológicas, semânticas e históricas dos termos: Bailly 2000; Chantraine 1983; Glare 2009; Houaiss \& Villar 2001, 2009; Liddell \& Scott 1996.

Dicionários especializados de geologia e biologia; livros e artigos científicos para as informações referentes aos termos pertinentes às áreas geológicas e paleontológicas.

Os dados obtidos foram analisados considerando-se fundamentalmente, etimologia, semântica e aspectos históricos dos nomes relacionados. A análise dos termos, de acordo com a sua origem, foi realizada citando-se os autores das áreas das ciências geológicas e paleontológicas e suas respectivas obras e os autores clássicos, incluindo-se: Hesíodo (1914) em "Teogonia" (Th); Homero (1919, 1920) em "Odisseia" (Od) e "Ilíada" (II); Lucano (1962) em "Pharsalia" (Phars); Ovídio (1892) em "Metamorphoses" (Met); Platão (1903), em "Phaedo"; Plínio, o Velho (1906), em "Historia Naturalis" (HN); Ptolomeu (2013), em "La Cosmographie de Claude Ptolemée" (Cosm.); Tácito (1906) em "Annales ab excessu divi Augusti" (Ann); Virgílio ([s.d.], 1900) em "Eneida" (E) e "Georgicon" (G). Para a localização dos termos ou passagens nas obras consultadas, as referências foram indicadas com o nome do autor, data, a abreviação do título, seguida do livro, do
1. Os termos designativos das unidades geocronológicas (Éon, Era, Período, Época) e os seus correspondentes das unidades cronoestratigráficas (Eonótema, Erátema, Sistema, Série) são indicados a seguir, considerando-se suas respectivas etimologias: Éon - a maior unidade de tempo geológico, comumente subdividido em Eras (do G. aiốn, aiônos, tempo, eternidade); Era unidade de tempo geológico composta de vários Períodos (do L. aera, aerae, uma idade, era); Período - unidade básica na escala de tempo geológico; indica o intervalo de tempo em que se formou um sistema litológico (do L. periŏdus; do G. períodos, caminho ao redor, período de tempo); Época - unidade de tempo geológico imediatamente inferior ao Período. Frequentemente corresponde ao lapso de tempo cujo equivalente estratigráfico é a Série (do G. epokhê, interrupção, limite); Eonótema, unidade cronoestratigráfica correspondente à Eon (do G. aiốn, aiônos e thema, depósito, pilha); Erátema (do L. aera, aerae, do G. thema); Sistema (do G. systēma, conjunto, sistema); Série (do L. seriēs, sucessão, fileira) (Glare 2009; Houaiss \& Villar 2001, 2009; Liddell \& Scott 1996; Stokes, 1969).

capítulo ou verso e da (s) linha (s) da referida obra. Os termos provenientes do grego foram indicados por "do G." e os de origem latina por "do L."

A denominação e a caracterização das Eras, Períodos e Épocas foram desenvolvidas sequencialmente a partir das unidades de tempo mais antigas para as mais recentes, com base no quadro das unidades geocronológicas (IUGS 2017) indicado na Fig. 1. Os nomes das unidades de tempo foram definidos segundo os critérios cronoestratigráfico e geocronológico. 


\begin{tabular}{|c|c|c|c|c|c|}
\hline \multicolumn{2}{|c|}{$\begin{array}{c}\text { Eonotema/ } \\
\text { Éon }\end{array}$} & $\begin{array}{c}\text { Eratema/ } \\
\text { Era }\end{array}$ & $\begin{array}{l}\text { Sistema/ } \\
\text { Período }\end{array}$ & $\begin{array}{r}\text { Série/ } \\
\text { Época }\end{array}$ & $\begin{array}{c}\text { Idade (Ma) } \\
\text { Início }\end{array}$ \\
\hline \multirow{16}{*}{\multicolumn{2}{|c|}{ 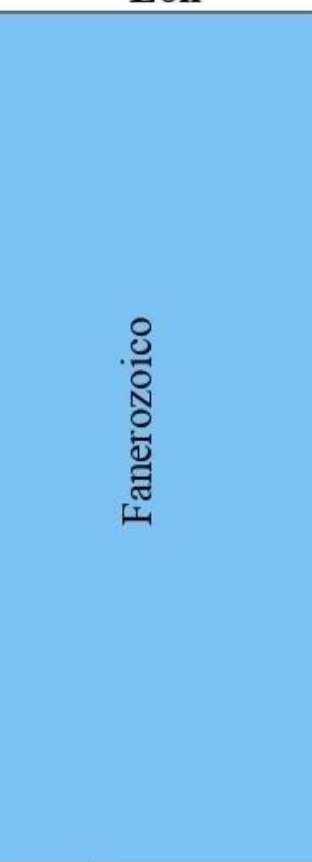 }} & \multirow{7}{*}{ Cenozoico } & \multirow{2}{*}{ Quaternário } & Holoceno & 0.0117 \\
\hline & & & & Pleistoceno & 2.58 \\
\hline & & & \multirow[t]{2}{*}{ Neógeno } & Plioceno & 5.333 \\
\hline & & & & Mioceno & 23.03 \\
\hline & & & \multirow{3}{*}{ Paleógeno } & Oligoceno & 33.9 \\
\hline & & & & Eoceno & 56.0 \\
\hline & & & & Paleoceno & 66.0 \\
\hline & & \multirow{3}{*}{ Mesozoico } & Cretáceo & & $\sim 145.0$ \\
\hline & & & Jurássico & & $201.3 \pm 0.2$ \\
\hline & & & Triássico & & $251.902 \pm 0,024$ \\
\hline & & \multirow{6}{*}{ Paleozoico } & Permiano & & $298.9 \pm 0.15$ \\
\hline & & & Carbonífero & & $358.9 \pm 0.4$ \\
\hline & & & Devoniano & & $419.2 \pm 3.2$ \\
\hline & & & Siluriano & & $443.8 \pm 1.5$ \\
\hline & & & Ordoviciano & & $485.4 \pm 1.9$ \\
\hline & & & Cambriano & & $541.0 \pm 1.0$ \\
\hline \multirow{3}{*}{ 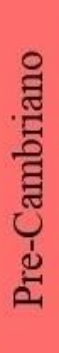 } & \multicolumn{4}{|l|}{ Proterozoico } & 2500 \\
\hline & \multicolumn{4}{|l|}{ Arqueano } & 4000 \\
\hline & \multicolumn{4}{|l|}{ Hadeano } & $\sim 4600$ \\
\hline
\end{tabular}

Figura 1. Escala do Tempo Geológico (modif. de International Union of Geological Sciences, IUGS 2017).

\section{RESULTADOS}

\section{1. Éon Hadeano}

O éon Hadeano, uma unidade geocronológica informal, iniciou-se há cerca de $4600 \mathrm{Ma}$ (milhões de anos) e teve uma duração de uns $600 \mathrm{Ma}$. Tratado por alguns geólogos como o mais antigo da história do planeta, este éon teve início quando ocorreu a acreção do material planetário, terminando com o surgimento das primeiras formações rochosas há cerca de 4000 Ma (Hine 2008).

Ao longo de quase toda a duração deste éon, o planeta não oferecia condições propícias ao aparecimento de vida (daí, o Hadeano ser caracterizado como abiótico [do G. a, sem, não e biōtikós, relativo à vida, que permite a vida]), um evento que deve ter ocorrido, muito provavelmente, só na fase final deste éon, por volta de uns $4000 \mathrm{Ma}$ (milhões de anos) atrás.

O termo "hadeano" significa relativo ou que pertence a Hades (do G. Hádēs, Háidēs) referindo-se aos infernos da mitologia grega ou ao deus que reinava nessas regiões. $\mathrm{Na}$ ilíada (Homero 1920, 15. 186-193), Hades é citado por seu irmão Posídon, como o senhor dos mortos e dos infernos, quando o deus dos mares contou como foram divididos os reinos subterrâneos, dos mares e dos céus entre ele e seus irmãos. O termo também se refere ao reino subterrâneo do deus Hades, em que se distinguiam várias regiões ${ }^{2}$ e alguns rios ${ }^{3}$ de 
aspectos sinistros, por onde eram conduzidas as almas dos mortos.

O equivalente latino do deus Hades era Plutão (do L. Plūton), o irmão de Júpiter e de Netuno. Esse deus foi citado por Virgílio (s.d. E, 7. 327) quando o poeta se referiu a Alecto, uma das Fúrias, que era detestada por seu próprio pai, o deus Plutão.

O nome Hadeano foi proposto em 1972 pelo geólogo e paleontólogo americano Preston Cloud (1912-1991). Em seu trabalho "A Working Model of the Primitive Earth", Cloud discutiu os éons pré-Cambrianos e a evolução da crosta terrestre, da atmosfera e da biosfera (Cloud 1972). O éon Hadeano caracterizou-se provavelmente pela adição de poeira e gases, bem como pela colisão de estruturas planetesimais sobre a superfície de um planeta cuja crosta estava em fase de solidificação, e com uma atmosfera e uma hidrosfera em desenvolvimento (Rafferty 2013a). Essas condições iniciais do planeta, em estado de fusão e muito quente, talvez tenham lembrado ao geólogo Cloud, as regiões infernais referidas na mitologia e nas religiões.

2. Entre os gregos antigos, os infernos eram lugares subterrâneos para onde eram destinadas as almas dos mortos que deveriam ser julgadas e, em seguida, recompensadas ou castigadas. O mundo subterrâneo era o reino do deus Hades e caracterizava-se pelas seguintes regiões: o Érebo (do G. Érebos; do L. Erěbus, divindade que personificava as trevas infernais); o Inferno dos Maus; o Tártaro (do G. Tártaros; do L. Tartărus, abismo infernal, região de suplícios) e os Campos Elísios (do L. élysios, do Elísio, a mansão dos heróis e dos virtuosos, nos infernos). O Érebo era a região mais superficial, próxima da terra, para onde iam os mortos insepultos. Ao Érebo seguia-se o Inferno dos Maus, a região do castigo, do remorso e da tortura; uma região de planícies áridas, de montanhas e lagos frios e quentes, de pântanos fétidos, de rios com águas ferventes; no Inferno dos Maus, as almas só conheciam o sofrimento, a dor, a tortura e a impossibilidade de sair dali (Commelin 2008). Depois dessa região infernal, encontrava-se o Tártaro, que era a prisão dos deuses; os Titãs, os Gigantes e os deuses que se confrontaram com Zeus e seus irmãos foram aprisionados no Tártaro (Brandão 1992). As almas dos virtuosos e dos bem- aventurados moravam nos Campos Elísios, uma região de pradarias verdejantes, de bosques com pássaros cantando e onde não havia dor e nem intranquilidade, mas somente, encantos e prazeres (Commelin 2008).

3. Nas regiões infernais encontravam-se vários rios. O Aqueronte (do G. Akhérōn, ontos, um dos rios dos infernos) era um rio de aspecto sinistro no qual as almas dos mortos, conduzidas por Caronte, deveriam atravessar até o local de sua permanência definitiva. O Cócito (do G. kốkȳtos; do L. Cōcȳtus ou Cōcȳtos, o rio dos gemidos, o rio das lágrimas), um afluente do Aqueronte, era um rio de águas lamacentas por onde eram conduzidas as almas dos mortos insepultos; estas almas deveriam errar por um período de cem anos para depois serem julgadas e conhecerem seus destinos. O Estige (do G. Stýx, Sty̆gós; do L. Styx, Sty̆gis, rio dos infernos, monstro, objeto horrível), um rio sombrio, de águas lentas, lamacentas e desagradáveis, era atravessado pelos mortos conduzidos no barco de Caronte (Commelin 2008). Homero, na Odisseia (Homero 1919), mencionou o Piriflegetonte (do G. pŷr, pyrós, fogo, chama e Flegetonte; do L. Phlegěthōn, Phlegěthontis, um dos riosafluentes do Aqueronte; de phlégein, brilhar, inflamar) como um rio de chamas sulfurosas. Platão, em sua obra Phaedo (Platão 1903), referiu-o como o rio por onde eram conduzidas as almas dos que ultrajaram seus pais. Esse rio, também conhecido como Flegetonte (do G. Phlegéthōn) circundava a prisão dos maus e, em vez de água, continha chamas sulfurosas(Commelin2008). OLete(doG. Léthē; do
L. Lēthē, um dos rios dos infernos; o rio do esquecimento; lêthē, um esquecimento), era um rio de águas lentas e silenciosas; os mortos bebiam de suas águas para não se lembrarem de sua vida terrestre (Brandão 1992).

\section{2. Éon Arqueano}

O Arqueano é o éon dos tempos précambrianos que se estende de cerca de 4000 Ma até 2500 Ma. Neste período da história do planeta em que, provavelmente, as rochas passavam por um processo de cristalização, um bloco continental de grande tamanho formou-se há cerca de uns $3000 \mathrm{Ma}$. Como as superfícies terrestres eram mais reduzidas, consequentemente as dos oceanos desse período eram mais extensas do que as atuais. De um modo geral, esse éon caracterizou-se, em sua maior parte, por um clima quente, com temperaturas variando de 55 a $80^{\circ} \mathrm{C}$. O Arqueano notabilizou-se pelo surgimento e desenvolvimento das primeiras formas de vida que, segundo o registro fóssil, eram representadas por organismos dos grupos das bactérias e arqueas que viviam nos oceanos (Kindersley 2009).

O termo Arqueano foi proposto pelo geólogo e zoólogo norte-americano James Dwight Dana (1813-1895), em 1872. Dana ao estudar as rochas das regiões próximas a Poughquag, no Estado de Nova lorque, caracterizou-as como rochas arqueanas que contêm gnaisse grosseiro cristalizado, feldspato com um pouco de albita branca e hornblenda. Essas rochas de idade Azoica (do G. a, prefixo indicativo de negação, sem, zôion, animal e ikós, que pertence a) são equivalentes às rochas azoicas do Canadá. Uma vez que o termo azoico passou a ser desusado, pois a era Azoica não foi totalmente sem vida (como seu nome sugere), Dana propôs o termo Arqueana (Archoean ou Archean) para substituí-lo (Dana 1872). Este termo originase do G. arkhaios, antigo, primitivo; de arkhé, relativo ao começo.

\section{3. Éon Proterozoico}

O éon Proterozoico estende-se de cerca de 2500 Ma até 541 Ma atrás. Este éon, que inclui as eras Paleoproterozoica (de 2500 a $1600 \mathrm{Ma}$ ), a Mesoproterozoica (de 1600 a $1000 \mathrm{Ma}$ ) e a Neoproterozoica (de 1000 a 541 
Ma), caracterizou-se pela formação e fragmentação de supercontinentes. Um destes supercontinentes, formado pela coalescência de fragmentos continentais, foi denominado Colúmbia e surgiu entre 2100 e 1800 Ma atrás. Sua fragmentação gerou blocos continentais que se agregaram por volta de $1000 \mathrm{Ma}$ atrás, formando o supercontinente Rodínia ${ }^{4}$. A fragmentação de Rodínia contribuiu para a formação do oceano Jápeto, há cerca de 600 Ma. A atmosfera e os oceanos do éon Proterozoico apresentaram muitas mudanças, mas 0 evento marcante desse éon foi o aumento significativo da concentração de oxigênio atmosférico, entre 2300 e 1800 Ma atrás (Windley 2014). O Proterozoico foi caracterizado por vários períodos de glaciação, um deles, logo no início e, alguns outros, até o final desse éon. Os depósitos glaciais do Neoproterozoico foram mais extensos do que os do Paleoproterozoico (Young 2013).

4. O supercontinente Rodinia foi gerado pela amalgamação dos crátons Arqueano-Paleoproterozoicos (Unrug 1997). O termo Rodinia origina-se do Russo "rodit", gerar criar ou "rodina", terra-mãe, terra natal. Foi proposto em 1990 por Mark e Diana McMenamin, que utilizaram o termo russo com referência ao fato de que Rodinia gerou todos os continentes atuais (Alden 2019).

O termo "Proterozoico" foi proposto pelo geólogo americano Samuel Franklin Emmons (1841-1911) em carta que endereçou ao geólogo Persifor Frazer (1844-1909), datada de 25 de maio de 1887 e publicada no International Geological Congress American commitee reports, Philadelphia (Emmons 1888). Nessa carta, Emmons escreveu: "Penso que as formações que ocorrem entre o Cambriano e o Arqueano devam ser incluídas em um grande grupo de categoria equivalente ao Arqueano, ao Paleozoico, etc. e, uma vez que o termo Paleozoico que, por longo uso, temse tornado indelevelmente impresso na classificação geológica, seria difícil abandonálo. Sugiro que o nome Proterozoico deva ser atribuído a este novo grupo significando que a vida ocorria anteriormente a aqueles outros grupos, sem que nos comprometêssemos, até agora, a afirmar que tenha sido o primeiro em que a vida surgiu no planeta" [pag. 59 da publicação] (Sears 1925). O termo 'proterozoico' compõe-se do G. proteros, anterior, o primeiro, inicial e zôîn, vida, ser vivo e ikós, sufixo indicativo de 'concernente a, relativo a'.

\subsection{O Éon Fanerozoico: eras Paleozoica, Mesozoica e Cenozoica}

O éon Fanerozoico segue-se aos éons précambrianos e inclui as eras Paleozoica, Mesozoica e Cenozoica, que compreendem os últimos $541 \mathrm{Ma}$, aproximadamente. Entre os principais eventos geológicos ocorridos no Fanerozoico destacam-se: a formação dos supercontinentes Gondwana ${ }^{5}$ no início desse éon e a Pangeia, no final da Era Paleozoica e início da Mesozoica; um clima que sofreu variações de quente a frio, mais seco e mais úmido, com períodos de glaciações. Em relação à evolução da vida, observou-se, ao longo do éon Fanerozoico, um aumento de complexidade ecológica associado a um aumento de complexidade morfológica. O aumento da complexidade ecológica deveu-se às transições importantes ocorridas nesse éon, incluindo-se: a explosão cambriana, a biodiversificação ordoviciana, a extinção em massa permotriássica, a colonização do ambiente terrestre com sua consequente biodiversificação e a colonização do ambiente aéreo (McNamara 2008). O grande aumento da biodiversidade no planeta iniciou-se com a radiação cambriana no começo desse éon e foi acrescida de cinco grandes eventos de extinção em massa e várias extinções menores, caracterizadas pela morte de muitos organismos de espécies que se extinguiram (Donev et al. 2019).

5. A Gondwana foi um supercontinente presente no hemisfério sul do qual se
originaram várias formações continentais (África, América do Sul, Austrália,
Índia e Antártida). O nome refere-se a uma região do norte central da Índia e
originou-se do termo sânscrito gondavana (de gonda, um povo dravídico que
era um dos grupos étnicos do sul da Índia, anterior aos indo-europeus e vana,
floresta) (Harper 2001-2020). O termo foi criado como Gondwanaland em
1885 pelo geólogo austríaco Eduard Suess (1831-1914). Em seu trabalho "Das
Antlitz der Erde" (A Face da Terra), Suess propõe denominar o continente de
Gondwanaland, com referência à "antiga flora de Gondwana, que era comum em
todas essas regiões e que, em sua maior parte, correspondia à Lemúria (região
zoogeográfica de Madagascar) dos zoogeógrafos" (Suess 1885). No latim, o termo
lemuriatem osignificado de "festa realizada em maio com a finalidade de aplacar
os espíritos dos mortos, dos espectros, dos lêmures (do L. lemures, os
fantasmas malévolos dos mortos) (Glare 2009).

O termo Fanerozoico foi proposto pelo geólogo norte-americano George Halcott 
Chadwick (1876-1953), em 1930, no abstract "Subdivisions of Geologic Time" (Chadwick 1930). Este geólogo propôs dividir o tempo geológico nos éons Fanerozoico e Criptozoico (do G. kryptós, oculto, secreto e zö̈kos, que concerne aos animais), incluindo no primeiro, as eras Paleozoica, Mesozoica e Cenozoica e, no segundo, o Pré-Cambriano. O termo Criptozoico não tem sido mais usado na literatura geológica (Gradstein et al. 2004). O nome fanerozoico compõe-se do G. phanerós, visível, evidente, aparente e zōïkos). Este éon caracteriza-se pela riqueza de vida animal e vegetal, e inicia-se com o período Cambriano da era Paleozoica.

\subsubsection{Paleozoica, A Era da Vida Antiga}

Era do éon Fanerozoico que se inicia há 541 Ma, estendendo-se até 251.9 Ma atrás. Nesta era incluem-se os seguintes períodos, do mais antigo para o mais recente: Cambriano, Ordoviciano, Siluriano, Devoniano, Carbonífero (que a escola americana subdivide em Mississipiano e Pensilvaniano, correspondendo respectivamente ao Carbonífero Inferior e Carbonífero Superior) e Permiano.

Sob um enfoque geológico, a Era Paleozoica iniciou-se com a fragmentação do supercontinente Panótia ${ }^{6}$, que gerou vários continentes; a maioria destes, agregou-se formando o supercontinente Pangeia ${ }^{7}$, no final dessa Era. Durante o paleozoico, os blocos continentais foram circundados por dois oceanos. Um deles, no início dessa Era, situado em sua maior extensão no hemisfério sul, foi denominado Jápeto ${ }^{8}$; o outro, desde os tempos neoproterozoicos, foi denominado Pantalassa $^{9}$ e suas águas circundaram a Pangeia (Scotese 2009). A era Paleozoica caracterizou-se pelo desenvolvimento da vida animal, com o surgimento da grande maioria dos filos atualmente presentes. Nessa era, surgiram, também, os representantes de todos os grandes grupos vegetais, com exceção de angiospermas.

6. Em 1995, o geólogo C. McA Powell propôs o nome "Pannotia" (Panótia) a fim de designar um supercontinente neoproterozoico. Para isso, baseou-se no nome "Pannotios", cunhado por Edmund Stump, em 1987, que se referia ao "ciclo de atividades tectônicas do final do precambriano e início do Paleozoico, ocorridos em toda a Gondwana. O termo origina-se do G. pân, tudo, todos e nótios, sul (Stump 1987). Powell sugeriu que esse supercontinente fosse denominado "Pannotia". Este autorjustificou a aplicação desse nome alegando que a maior parte desse supercontinente localizava-se no hemisfério sul (Powell \& Young 1995).

7. A Pangeia era um supercontinente único, formado no final da era Paleozoica (período Permiano), que se manteve íntegro até que, há cerca de $225 \mathrm{Ma}$, no período Triássico, começou a fragmentar-se gerando uma grande massa continental no hemisfério norte, a Laurásia, e outra massa continental no sul, a Gondwana. Durante a ocorrência da Pangeia, esta massa continental era circundada pelas águas de um oceano universal que alguns autores denominam "Panthalassa" (Allaby 2009). O termo "Pangaea" ocorre na mitologia grega com o significado de um sítio montanhoso de batalha durante a titanomaquia (guerra entre os Titãs e os deuses do Olimpo). O termo é, também, mencionado por autores latinos. Virgílio (s.d. G, 4. 462) referiu Pangaea como uma alta montanha da Trácia. O poeta romano Marco Aneu Lucano (39-65), em sua obra Pharsalia (1962 Phars.1.679), referiu-o como uma montanha cheia de neve (Pangaea nivosis). Na literatura geológica, o nome "Pangaea" foi referido pelo meteorologista e geofísico alemão Alfred Wegener (18801930) que, em seu trabalho de 1920 , ao comentar a migração dos continentes, mencionou a Pangāa (Pangaea) do Carbonífero (Wegener 1920). O nome Pangeia origina-se do G. pân e Gaîa, Geia com os sentidos de Terra, como parte do universo, como ambiente terrestre e como a personificação da deusa Terra (Bailly 2000). Na Teogonia, Hesíodo menciona a deusa Geia como a fundação de todas as coisas imortais (Hesíodo 1914, Th. 117-118).

8. Entre cerca de 600 e 400 Ma atrás, no hemisfério sul, entre os continentes Laurência (nome originado das montanhas Laurencianas, no Canadá; do L. Laurentǐus, de Laurento, cidade do Lácio) e Báltica (do L. Baltĭa, segundo os latinos, nome da Escandinávia), havia um oceano denominado originalmente Protoatlântico e, posteriormente, Jápeto. Esse oceano existiu desde o final do Neoproterozoico até o final período Siluriano, na Era Paleozoica (Mason 1988). O nome Jápeto origina-se do G. lapetós; do L. İapĕtus. Refere-se ao Titã, filho de Urano e Geia que, na guerra contra os deuses do Olimpo, foi derrotado e aprisionado no Tártaro (Brandão 1992). O nome desse Titã foi citado por Homero e por Hesíodo. Na ilíada, Homero (1920, II. 8.478-479) mencionou as regiões mais profundas do Tártaro, abaixo da terra e do mar, onde Jápeto e Crono habitavam. Hesíodo (1914 Th. 507-509) citou o termo quando relatou que Jápeto tomou como esposa, Clímene, a filha de Oceano e, dessa união, foi gerado o intrépido Atlas. Os autores latinos Virgílio e Ovídio também mencionaram Jápeto em suas obras. Virgílio (1900 G, 1. 278-279) referiu o termo quando citou o parto abominável da mãe Terra, gerando Coeus, Jápeto e Tifeu (Tifão). Ovídio (1892 Met. 1. 82-83) relatou que o filho de Jápeto formou o homem a partir de terra misturada a águas pluviais, plasmando-o à imagem de deuses. Esse termo foi aplicado ao oceano pelos geólogos Walter Harland e R. Gayer em 1972, que propuseram a substituição do nome do paleoceano Protoatlântico por Jápeto (Harland \& Gayer 1972). Este nome foiIhe atribuído porque esse paleoceano foi considerado como o precursor do Atlântico (do G. Átlas, antos; do L. Atlās, antis) e, segundo a mitologia, o Titã Atlas (Átlantos) foi filho de Jápeto.

9. O paleoceano Pantalassa, de tamanho equivalente a um hemisfério terrestre, das Eras Paleozoica e Mesozoica, circundava a Pangeia e originou o atual oceano Pacífico (Arias 2008). O nome Pantalassa origina-se do G. pân e thálassa, mar. Esse termo foi introduzido na literatura geológica pelo geólogo austríaco Eduard Suess. Em seu trabalho de 1893, esse geólogo afirmou que "somos induzidos a inferir que deve ter existido uma hidrosfera universal ou "panthalassa", que cobria todo o planeta em tempos pré-paleozoicos" (Suess 1893).

O termo paleozoico origina-se do G. palaiós, antigo, velho; zôion, vida, ser vivo e ikós, sufixo indicativo de 'concernente a, relativo a'. Esse termo foi atribuído em 1838 pelo geólogo inglês Adam Sedgwick, quando estudava as séries inglesas de rochas estratificadas dispostas subjacentemente aos "arenitos vermelhos antigos" (Old Red Sandstone). Estes arenitos correspondem a uma sequência espessa de rochas, de origem primordialmente terrestre, distribuídas pelo noroeste europeu, Escandinávia, Groenlândia e nordeste do Canadá, abrangendo parte do 
período Devoniano, aproximadamente de 416 a 359 Ma atrás (Rafferty 2007).

Por fim, Sedgwick denominou classe I ou sistema Protozoico (do G. prôtos, primeiro, original e zōikós, relativo à vida animal) a um grupo de rochas dispostas mais abaixo de outro grupo a que caracterizou como Classe II ou série Paleozoica. Nesta série, o autor incluiu todos os grupos de formações entre a classe I e a "Old Red Sandstone", que foram subdivididos em Sistema Cambriano Inferior, Sistema Cambriano Superior e Sistema Siluriano (Sedgwick 1838).

\subsubsection{CAMBRIANO}

Sistema de rochas do Paleozoico Inferior. É o período em que se iniciou a era Paleozoica há cerca de $541 \mathrm{Ma}$, tendo terminado há aproximadamente $485.4 \mathrm{Ma}$.

O período caracterizou-se por um movimento relativamente rápido de placas e, na fase inicial, foi marcado pela fragmentação do supercontinente Panótia; outro fato marcante do cambriano foi a agregação de massas continentais que formaram o supercontinente Gondwana. O período caracterizou-se por um clima quente e árido; o registro geológico fornece poucas indicações de um clima quente e úmido (Kindersley 2009). Os primeiros organismos com esqueletos mineralizados ocorreram no Cambriano (Allaby 2009). No começo do período, um evento evolutivo notável - A Explosão Cambriana - caracterizou-se pelo surgimento de vários grupos de animais em um intervalo de poucos milhões de anos. Este surto de vida animal levou ao aparecimento de braquiópodes, trilobitas, equinodermos e, há cerca de 540 milhões de anos, de cordados, representados inicialmente por Pikaia $^{10}$ e pelos primeiros vertebrados. Estes últimos, datados de 530 milhões de anos, foram descobertos na China e apresentavam de 2 a $3 \mathrm{~cm}$ de comprimento. Caracterizavamse morfologicamente pela presença de elementos vertebrais representativos de uma coluna vertebral (Kindersley 2009).
O termo cambriano compõe-se de "Cambria" (do L. med ${ }^{11}$ Cambria) e "ano", do L. anus, relativo a. Cambria é nome antigo, dado pelos romanos ao País de Gales. Cambriano é um nome derivado do topônimo alatinado Cambria, variante de Cumbria, termo latinizado que provém de Cymry, galeses (Onions 1985).

Em ciências geológicas, o termo foi empregado pela primeira vez, em 1835, pelo geólogo britânico Adam Sedgwick. Em seus estudos dos estratos sedimentares mais antigos na Inglaterra e no País de Gales, Sedgwick (em um trabalho com o geólogo escocês Roderick Impey Murchison [17921871]) referiu-se a um grupo de rochas, denominando-as grupo Cambriano (Inferior, Médio e Superior) (Sedgwick \& Murchison 1835).

10. Pikaia era um animal pisciforme que viveu na época do Cambriano Médio. Sua posição taxonômica parece estar mais próxima de um cordado primitivo (mais especificamente do anfioxo, um cefalocordado). Esse animal foi descoberto na formação Burgess, datando de aproximadamente $505 \mathrm{Ma}$ atrás e apresentava um comprimento de, no máximo, $5,5 \mathrm{~cm}$. Sua espécie foi descrita com o nome de Pikaia gracilens pelo paleontólogo norte americano Charles Doolittle Walcott (1850-1927), em 1911. Walcott descreveu o representante dessa nova espécie como "um poliqueta de corpo delgado, muito segmentado, de cabeça pequena, com olhos bem desenvolvidos, parapódios nos segmentos anteriores, canal entérico reto e boca e ânus nas extremidades do corpo" (Walcott 1911). Seu nome genérico Pikaia origina-se de Pika (o termo piika, em língua tungue, designa um pequeno mamífero semelhante ao coelho, que vive na Sibéria e na América do Norte), uma montanha situada na província de Alberta, no Canadá; seu nome específico origina-se do L. grăcilěns, delgado, fino, referindo-se à forma de seu corpo (ROM 2011).

11. L. med. (latim medieval) - a língua latina falada na Europa na Idade Média, entre as datas aproximadas de 500 a 1500, anos que marcam respectivamente "aqueda do império romano do Ocidente" e o "início da Renascença".

\subsubsection{ORDOVICIANO}

Sistema de rochas situado entre o Cambriano e o Siluriano. Período geológico da era Paleozoica que se iniciou há cerca de 485.4 Ma e terminou há uns $443.8 \mathrm{Ma}$.

No período Ordoviciano havia três paleoceanos principais: Jápeto, que separava os crátons $^{12}$ de Laurência e SibériaKazaquistão do cráton Báltica; o mar Paleotétis, que separava os crátons Avalônia, Báltica e Kazaquistão, do supercontinente Gondwana; o oceano Pantalássico, que cobria o hemisfério norte em sua quase totalidade (Kindersley 2009).

12. A porção da litosfera continental ou da base de um oceano, imóvel e relativamente estável, ou seja, não mais afetada por atividade orogênica, é 
denominada cráton. Essa estabilidade tem ocorrido por um período de aproximadamente 1000 Ma. O escudo canadense é um exemplo de cráton (Allaby 2013). No Brasil, distinguimos os crátons Amazônico, o do São Francisco, o de São Luís e o do Rio de La Plata. O termo cráton (ou crato) origina-se do G. krátos, força, solidez; foi aplicado com referência à solidez dessas áreas continentais. Esse termo já se encontra na llíada (Homero 1920, 7.142-143) aplicado com o sentido de 'força': "durante uma batalha, Licurgo matou seu oponente, o rei Areito, não pela força (krátei), mas pela astúcia". Na Odisseia (Homero 1919, 9. 391-393), o termo foi referido quando Odisseu e seus companheiros cegaram o ciclope Polifemo; neste momento, o poeta relatou que "quando um ferreiro mergulha um grande machado ou um enxó em água fria para temperá-lo, ouve os sons sibilantes do metal candente, pois daí vem a força do ferro" Chantraine (1983) refere um termo composto "krataípedos", solo duro, mencionado na Odisseia no momento em que Euricleia, a serva de Penélope, viu Odisseu em pé e, em sua volta, no chão duro (krataípedon), os corpos estirados dos homens que matou (Homero Od. 1919, 23. 45-47). O conceito de cráton apareceu na literatura geológica em 1921, proposto pelo geólogo austríaco Leopold Kolber (1883-1970), que cunhou o termo kratogen para explicá-lo. Posteriormente, em 1933, o geólogo alemão Hans Wilhelm Stille (1876-1966) propôs a redução do termo kratogen para kraton (Şengör 2003).

Nesse período, as altas taxas de $\mathrm{CO}_{2}$ na atmosfera geraram um efeito estufa, cujas temperaturas proporcionaram um clima quente do equador aos polos. Em latitudes mais altas, no entanto, ocorriam climas mais frios. Em alguns pontos, evidenciaram-se depósitos glaciais e, no final do período, constatou-se a ocorrência de uma glaciação que avançou até o início do Siluriano (Holland 2018).

Nos mares do período Ordoviciano houve uma grande diversificação da vida animal a que se denominou radiação ordoviciana. Nesse período, provavelmente a vida já se desenvolvia em ambiente terrestre. Há evidências de trilhas produzidas por artrópodes anfíbios, possivelmente euticarcinoides, em arenitos eólicos do Cambriano-Ordoviciano do sudeste de Ontário, Canadá (Macnaughton et al. 2002). No registro fóssil de plantas registrou-se a descoberta de um possível megafóssil de musgo (Retallack 2017). O final do período presenciou uma extinção em massa de animais do ambiente marinho (Holland 2018).

O termo Ordovices refere-se a um povo da região setentrional da província de Gales e foi mencionado por Tácito (1906 Ann, 12. 33) que, durante a insurreição na Bretanha, relatou a vitória do general Públio Ostório Escápula sobre o líder bretão Carataco, em uma região do território dos Ordovices. Cláudio Ptolomeu, em sua obra "Geografia" (Ptolomeu 2013, 2.2) mencionou os Ordovices como um povo que vivia a alguma distância a oeste de onde viviam os Brigantes.
O nome desse período foi cunhado pelo geólogo inglês Charles Lapworth (1842-1920), em 1879. O autor aplicou esse nome ao sistema situado entre o Siluriano e o Cambriano, este último caracterizado como o mais basal do Paleozoico; o nome ordoviciano tem o significado de "relativo aos Ordovices", o povo que habitava essa região (Lapworth 1879). O termo ordovices compõe-se do Celta ordo, martelo e, provavelmente, weik, combater, conquistar; "os que combatem com martelo" (Harper 2001-2020a; Matasovic 2008).

\subsubsection{SILURIANO}

Sistema geológico situado entre o Ordoviciano e o Devoniano. Período geológico da era Paleozoica que se iniciou há 443.8 Ma e terminou há cerca de 419.2 Ma.

O nível dos mares silurianos era bem mais elevado do que os atuais (devido ao processo de deglaciação ocorrido no início do período) ao passo que nos continentes as elevações eram, em geral, bem menores. Durante esse período, provavelmente, predominava um clima zonalmente uniforme no hemisfério norte. Já, no hemisfério sul, com o supercontinente Gondwana presente, provavelmente ocorriam amplas variações de temperatura, com períodos de verão e de inverno (Johnson 2020).

A vida marinha no Siluriano era caracterizada por recifes de corais, que eram bastante comuns, além de uma grande variedade de ágnatos, de acantódios (formas primitivas de peixes mandibulados), e elasmobrânquios (Johnson 2020). Tem-se admitido, até há alguns anos, que os peixes ocorriam escassamente nos mares do siluriano, ou então, eles foram predominados por formas ágnatas desses mares. Esses peixes deveriam ser de pequeno tamanho (cerca de $30 \mathrm{~cm}$ ). No entanto, descobriu-se recentemente na formação Kuanti, no sudoeste da China, um fóssil de osteíctie de cerca de $1 \mathrm{~m}$ de comprimento; era um predador dos mares silurianos de aproximadamente 423 Ma atrás. 
Tal descoberta sugere que os gnatostomados silurianos poderiam ser mais diversos e distribuídos do que anteriormente se supunha (Choo et al. 2015). No ambiente terrestre, o interior dos continentes era praticamente desprovido de vida; os fungos estavam presentes e as plantas vasculares iniciavam sua colonização do meio terrestre a partir de regiões próximas das águas; artrópodes, tais como milípedes e aracnídeos surgiram nesse período. No Siluriano, ocorreram vários eventos de pequenas extinções e radiações (Johnson 2020).

O termosilures (do L. silūres, povo belicoso que habitava o sudeste do País de Gales) foi referido por Tácito (1906 Ann. 12.33) quando este autor relatou que o exército do general Públio Ostório Escápula marchou contra os Silures, um povo guerreiro do País de Gales, liderado por Carataco, considerado o maior dos generais dos bretões. Plínio (1906 HN, 4. 41) mencionou o território dos silures quando descreveu sua posição geográfica em relação à Hibérnia (uma das ilhas britânicas, a Irlanda).

A porção superior das grauvacas (tipo de arenito detrítico no qual se observa maior concentração de argilas e feldspatos em relação ao quartzo; do Al. Grauwacke, grés, psamito) de origem marinha, do sul de Gales, foi descrita por Murchison (Woodford 1970). A fim de atribuir um nome ao sistema que estudava, caracterizado por depósitos que jazem entre a "old red sandstone" e as rochas ardosianas do país de Gales, este autor comentou que, pelo fato de a massa rochosa localizar-se em uma região que já fora habitada pelos Silures, foi motivado a denominá-lo sistema Siluriano (Murchison 1835). Seu trabalho "The Silurian System" foi publicado em 1839, quatro anos depois dessa descrição inicial (Woodford 1970).

\subsubsection{DEVONIANO}

Sistema geológico situado entre o Siluriano e o Carbonífero. Período geológico da era
Paleozoica que se iniciou há cerca de 419.2 Ma e terminou há uns 358.9 Ma.

No Devoniano, os continentes de Euramerica (gerado pela colisão de Laurência e Báltica) e Gondwana aproximaram-se, em virtude da intensa atividade tectônica ocorrida nesse período. Os níveis dos oceanos eram mais elevados, com as regiões litorâneas cobertas por mares rasos. O paleoceano Pantalassa tinha suas águas distribuídas por todo o planeta. Esse período caracterizou-se por ser relativamente quente e, provavelmente, sem a ocorrência de depósitos glaciais, com exceção das regiões polares (House 2020). No ambiente marinho, recifes de corais e vários grupos de invertebrados, tais como poríferos e braquiópodes eram comuns; os trilobitas, no entanto, não foram tão bem sucedidos. Entre os vertebrados, os ágnatos declinavam e os peixes tiveram uma predominância geral (Kindersley 2009). Este período, em que surgiram os grandes peixes predadores, tem sido considerado pelos especialistas como um momento de transição no tamanho e na diversidade de formas primitivas de gnatostomados (Choo et al. 2015).

No Devoniano, as plantas colonizaram o ambiente terrestre. Entre os invertebrados, os miriápodes e os aracnídeos já estavam presentes; os insetos sem asas originaram-se nesse período, que também se destacou pelo surgimento dos primeiros vertebrados terrestres (tetrápodes) (Kindersley 2009).

O nome Devoniano refere-se à região de Devon, onde em 1840, os geólogos Adam Sedgwick e Roderick Murchison estudaram um terreno contendo um grupo de rochas de origem marinha. Esses geólogos propuseram o nome de sistema Devoniano para designar coletivamente a esse grupo de rochas das regiões de Cornwal e de Devonshire (Sedgwick \& Murchison 1840), do sudoeste da Inglaterra.

O termo devoniano origina-se do topônimo inglês Devon ou Devonshire (do lat. med. Devonia) e significa "que pertence a Devon" (Onions 1985). 


\subsubsection{CARBONÍFERO}

Sistema geológico situado entre o Devoniano e o Permiano. Período geológico da era Paleozoica que se iniciou há cerca de 358.9 Ma e terminou aproximadamente, há 298.9 Ma.

No período Carbonífero, os blocos cratônicos (Laurência, Báltica e Avalônia) que constituíram a Laurússia (de Laurência + Rússia), aproximavam-se da Gondwana dando início à formação da Pangeia (Klappenbach 2020). Neste período ocorreram reduções do nível dos oceanos (eustasia ${ }^{13}$ negativa) até o momento de transição MississipianoPensilvaniano e, aumentos desse nível (eustasia positiva), em quantidades reduzidas, no final do período (Haq \& Schutter 2008). Durante o Carbonífero, houve um aumento das temperaturas globais; nas regiões equatoriais, predominaram climas quentes e úmidos; nas regiões de latitudes médias havia uma estreita faixa de clima árido, e, as regiões de altas latitudes apresentavam condições climáticas temperadas e frias (Kindersley 2009). Em relação aos organismos, esse período caracterizou-se pela diversidade de invertebrados marinhos e dos peixes, tanto no ambiente marinho quanto no dulcícola. No ambiente terrestre, houve diversificação de plantas vasculares dos grupos de licopódios, esfenópsidas, cordaitales, pteridospermas e filicópsidas; entre os vertebrados, houve grande desenvolvimento dos anfíbios e surgimento dos primeiros répteis (Manger 2020).

13. Os movimentos tectônicos, ou então, o aumento ou redução dos glaciares do planeta, ocasionam mudanças globais no nível dos oceanos a que se denomina eustasia. Se esse nível sobe, a eustasia é positiva; se desce, é negativa. Foi Eduard Suess quem introduziu na literatura científica o conceito de eustasia. Em um dos capítulos de seu livro, "Das Antlitz der Erde", Suess comentou a respeito das oscilações do nível dos oceanos, caracterizando os movimentos eustáticos negativos e os eustáticos positivos (Suess 1888). O termo eustasia origina-se do G. eu, bem e stásis, estabilidade, fixidez. Suess explicou os movimentos eustáticos como sendo oscilações do nível dos oceanos de dois tipos: transgressão (fase de inundação das margens continentais) e regressão (fase de exposição das margens continentais) (Rovere et al. 2016).

Os geólogos William Daniel Conybeare (17871857) e William Phillips, descreveram, em 1822, uma classe de rochas constituídas por grandes depósitos de carvão, que eram mais proeminentes quando comparados aos de outros sistemas. Estes depósitos repousam sobre os de calcários e de arenito. Os autores propuseram para esta série o nome de "carbonífero" (Conybeare \& Phillips 1822). O nome "carbonífero" origina-se do L. carbō, carbōnis, carvãoeferō,ferre, levar, portar.

\subsubsection{PERMIANO}

Sistema geológico situado entre o Carbonífero e o Triássico. Período geológico que sucedeu ao Carbonífero e encerrou a era Paleozoica, tendo-se iniciado há cerca de 298.9 Ma e terminado há uns 251.9 Ma.

No período Permiano, a grande região continental era representada fundamentalmente pela Pangeia, resultante da união dos supercontinentes Laurásia e Gondwana. Os oceanos Pantalassa e Paleotétis circundavam as regiões continentais desse período. As atividades de glaciação originadas no Carbonífero tiveram continuidade no Permiano Inferior, com avanços e recuos repetidos dos glaciares até o Permiano Superior, quando praticamente desapareceram. O clima tornou-se, então, bastante seco com várias regiões do continente apresentando áreas desérticas (Kindersley 2009).

Nesse período verificou-se a extinção de vários grupos de plantas arcaicas, mas houve diversificação das coníferas, plantas que tiveram origem no período Carbonífero. Constata-se também, o surgimento de cicadáceas, que se distribuíram globalmente na era Mesozoica e das gnetales, providas de características que permitem relacioná-las com as angiospermas (Palmer 2009). No ambiente marinho, houve uma extinção de invertebrados, sobretudo no Permiano Superior, com a drástica redução dos níveis dos oceanos. Mesmo com esta alteração, os peixes actinopterígios prosseguiram com sua diversificação (Kindersley 2009). No ambiente terrestre, entre os vertebrados, os répteis diversificaram-se e foram substituindo os anfíbios. No Permiano Inferior, o grupo predominante de répteis foi 0 dos pelicossauros que, posteriormente, foram 
sucedidos pelos terápsidas (répteis mamaliformes), originados de formas carnívoras de pelicossauros (Monroe \& Wicander 2014).

O evento mais marcante do Permiano foi uma grande extinção em massa que ocorreu no final do período (extinção $\mathrm{P}-\mathrm{Tr}$ Permotriássica), a maior da história da vida no planeta. Este evento catastrófico, que provocou a dizimação de mais de $90 \%$ de todas as espécies que existiam naquela época, foi bastante severo tanto para os organismos marinhos quanto para os terrestres (Wignall 2009).

Em 1841, o geólogo britânico Roderick Murchison, estudava a região carbonífera de Donetz e as rochas adjacentes do mar de Azof, na Rússia. Murchison observou que o Sistema Carbonífero é encimado por uma vasta série de camadas de marga (argila calcária), xistos, calcários, arenitos e conglomerados, situada ao leste do rio Volga. Este geólogo atribuiu a esta série o nome de Sistema Permiano (Murchison 1841). Esse nome origina-se do topônimo Perm, região situada a leste do rio Volga, às margens do rio Kama, nas faldas dos montes Urais. O termo Permiano compõe-se do russo Perm, nome de uma região da Rússia e-iano, ano, do L. anus, relativo $a$; sufixo indicativo de nome de localidades.

\subsubsection{Mesozoica, a Erada Vida Intermediária}

Era geológica do éon Fanerozoico, entre a Paleozoica e a Cenozoica, tendo-se iniciado há cerca de 251.9 Ma e terminado por volta de 66 Ma atrás. Nessa era, o planeta assistiu ao surgimento de mamíferos e aves, além de um grande desenvolvimento da vida reptiliana e, no final, uma extinção em massa dos seres vivos. A era Mesozoica inclui três períodos, do mais antigo para o mais recente: Triássico, Jurássico e Cretáceo.

O nome "Mesozoica" foi atribuído a essa era pelo geólogo britânico John Phillips (18001874), em 1840. Este autor escreveu o artigo "Série Paleozoica" em "Penny Cyclopaedia", indicando nesse trabalho que, "tantos quantos forem os sistemas ou combinações de formas orgânicas detectáveis na crosta terrestre, tantos serão os termos correspondentes (tais como Paleozoico, Mesozoico, Cenozoico) para designá-los" (Phillips 1840). O termo Mesozoico compõese de G. mésos, meio, centro; zôion, vida, ser vivo e ikós, sufixo indicativo de "concernente a, relativo a". Esse termo refere-se à vida intermediária (média) nessa era, que na escala geológica, situa-se entre a Paleozoica e a Cenozoica.

\subsubsection{TRIÁSSICO}

Sistema geológico situado acima do Permiano e abaixo do Jurássico. Período que inicia a era Mesozoica há cerca de uns 251.9 Ma tendo terminado há uns 201.3 Ma.

No período Triássico, as massas continentais concentravam-se na Pangeia, circundada quase totalmente por um oceano global e pelo mar de Tétis $^{14}$, a leste, ao longo do equador (Davis 2019). Durante esse período, os climas foram predominantemente quentes. As condições climáticas devem ter sido mais homogêneas do que as atuais. A maior parte das áreas terrestres do supercontinente Pangea apresentava um clima árido (Logan 2021). 14. Tétis (do G. Tēthýs, deusa marinha), a filha de Geia e de Urano era a esposa de
Oceano e mãe dos Rios e das Oceânides. O mar de Tétis, de natureza
epicontinental (mar de águas rasas que cobrem as bordas do continente),
separava os dois supercontinentes: a Laurásia ao norte e a Gondwana, ao sul.
Esse mar formou-se assim que houve a fragmentação da Pangeia, na era
Mesozoica (Tang 2018). Na llíada, a deusa Tétis é mencionada quando Hera,
respondendo à Afrodite, disse-lhe que iria visitar, nos limites do mundo, a mãe
Tétis e o deus Oceano, de quem todos os deuses se originaram e que haviam
recebido, em sua casa, a deusa suprema do Olimpo e dela cuidaram (Homero
1920, II. 199-202). Na Teogonia, Hesíodo (1914 Th., 133-138) relatou que da
união de Geia e Urano foram gerados entre outros Titãs: Oceano, Hipérion,
Jápeto, Rea, Mnemósine e a encantadora Tétis. Depois deles, nasceu Crono, o
mais terrível de seus filhos. Virgílio (1900 G, 1. 29-31) mencionou essa deusa
quando se referiu a César Augusto, dizendo: "se você vier como deus dos
mares ilimitados e os marinheiros adorarem somente sua divindade, Tétis, com
o dote de todas as suas ondas, teráa vontade de casá-locom sua filha".

Vários eventos biológicos importantes podem ser destacados nesse período. No ambiente marinho houve uma grande extinção da vida no final do período. Entre os fatores que, provavelmente, influenciaram nessa extinção, incluem-se as alterações ambientais induzidas pelos níveis de $\mathrm{CO}_{2}$, tais como aquecimento 
global, mudanças no nível dos oceanos e acidificação de suas águas (Dunhill et al. 2018).

No ambiente terrestre, a flora composta de licopódios, samambaias e pteridospermas do Permiano foi, fundamentalmente, substituída pelas cicadáceas, ginkgoáceas e coníferas. No documentário fóssil animal, foi constatada uma grande diversificação dos insetos (Palmer 2009). Dois eventos marcantes na evolução dos vertebrados, ocorridos no final do triássico, foram o surgimento dos dinossauros, que iriam predominar no período seguinte da era Mesozoica e o aparecimento dos primeiros mamíferos, originados de répteis do grupo dos terápsidas. o período, que se iniciou quando ainda continuava a extinção em massa do final do Permiano, concluiu-se com outra extinção.

O termo Triássico foi introduzido na literatura científica pelo geólogo alemão Friedrich August von Alberti (1795-1878). Este geólogo atribuiu o nome Trias quando descreveu na Alemanha, em 1834, uma sequência de estratos rochosos, compostos de três unidades e situados acima das rochas do Permiano e abaixo das do Jurássico. Esse nome refere-se ao fato de que o autor, ao estudar essa formação, pôde observar que, nessa região, o sistema caracterizava-se por três porções de rochas que se contrastavam (Stokes 1969). Von Alberti ao analisar as três estruturas, até então separadas em três formações, achou que as três juntas ajustavam-se melhor ao conceito de formação, denominando-a "Trias" (Von Alberti 1834). Em 1841, o nome Triássico foi proposto em substituição ao anterior "Trias". O termo Triássico origina-se do G. trias, o número três; do lat. tard. grupo de três, tríade e do sufixo ikós.

\subsubsection{JURÁSSICO}

Sistema geológico situado entre o Triássico e o Cretáceo. Período da era Mesozoica que se iniciou há cerca de 201.3 Ma e terminou há uns 145Ma.

Neste período ocorreram mudanças significativas na configuração dos continentes e dos paleoceanos, bem como na diversificação da vida. Com a fragmentação da Pangeia, a Laurásia começou a se afastar da Gondwana, propiciando a formação do oceano Atlântico e do Golfo do México; em todos os continentes verificaram-se mudanças nos níveis dos mares. No Jurássico, o clima foi geralmente quente; temperaturas mais baixas foram notadas no Jurássico Médio para depois aumentarem no Jurássico Superior (Tang 2019).

No ambiente marinho, os invertebrados foram bem representativos com dois grupos de cefalópodes: os amonites e os belemnites; entre os vários tipos de répteis destacavamse os ictiossauros e os plesiossauros. As plantas predominantes no ambiente terrestre foram as cicadófitas e as coníferas. A transição de fauna do Triássico para o Jurássico evidenciou o predomínio dos dinossauros entre os répteis; os pterossauros, répteis voadores, também se diversificaram. Esse período foi caracterizado pelo surgimento das primeiras aves e a diversificação de pequenos mamíferos térios (incluindo os placentários), que deveriam ocupar o nicho ecológico dos atuais grupos de insetívoros e de roedores (Kazlev 2002a).

O termo Jurássico foi cunhado pelo naturalista e mineralogista francês Alexandre Brongniart (1770-1847), em 1829. Em seu trabalho "Tableau des Terrains qui composent L'écorce du Globe", este naturalista referiu-se aos terrenos dos montes Jura (localizados na fronteira entre Suíça e França). Brongniart, ao analisar estes terrenos, preferiu atribuir-Ihes a denominação de jurássicos (jurassiques) "pelo fato de indicarem terrenos compostos de diferentes rochas, encontrando-se numa posição geognósica (do G. gê, terra e gnôsis, conhecimento, ciência) análoga à da cadeia do Jura" (Brongniart 1829). O nome "Jura" foi proposto pelo naturalista e explorador Alexander Von Humboldt (1769-1859), em 
1795, quando este autor descreveu a formação dessas montanhas como "calcários do Jura" (Durand-Delga 2006). O termo "Jura" origina-se de iuris que em linguagem gaulesa tem o significado de "montanha florestal"; em latim significa "monte da Gália"; cadeia de montanhas do sul da França (Harper 20012020b).

\subsubsection{CRETÁCEO}

Sistema geológico situado acima do Jurássico e abaixo do Terciário. Período da era Mesozoica que sucedeu ao Jurássico, tendose iniciado há cerca de 145.0 Ma e terminado há aproximadamente 66.0 Ma.

No início desse período havia dois supercontinentes: a Laurásia ao norte e a Gondwana, ao sul. O nível dos oceanos era mais alto do que o atual, cerca de 100 a 200 m no Cretáceo Inferior e 200 a 300 m no Cretáceo Superior. Nesta época, os continentes mostravam uma configuração mais próxima da atual e os oceanos também exibiam uma conformação mais semelhante à de hoje. O oceano Atlântico já estava presente; o mar de Tétis ainda separava grande parte dos continentes que representavam a Laurásia e a Gondwana (Hansen \& Koch 2018). O Cretáceo caracterizou-se por um clima quente e, próximo ao final, destacou-se como um dos mais quentes do Éon Fanerozoico. Mesmo com essas condições climáticas de efeito "supergreenhouse" (super efeito estufa) nesse período, conhecido como Turoniano (de 93,9 a 89,8 Ma atrás), há evidências de um processo de glaciação que durou cerca de 200 mil anos (Bornemann et al. 2008).

De algumas décadas para cá, as pesquisas paleontológicas têm mostrado que no período Cretáceo vários grupos de organismos apresentavam uma distribuição global, incluindo-se foraminíferos, amonites, tubarões, dinossauros, répteis marinhos (ictiossauros, plesiossauros e mosassauros), mamíferos primitivos e, no final do período, as angiospermas (Kosla \& Lucas 2016). Estas plantas originaram-se no Cretáceo e seus fósseis mais antigos datam de aproximadamente 122 Ma atrás, um momento do período em que ainda havia o predomínio das gimnospermas. Entre os invertebrados terrestres, destacavam-se os insetos que, com o surgimento de grupos sociais, incluindo-se as abelhas e vespas, puderam desenvolver um processo de coevolução com as angiospermas. Entre os grupos de vertebrados, encontravam-se quelônios, serpentes, rãs e salamandras, porém, os dinossauros eram, ainda, predominantes (Kosla \& Lucas 2016). No ar, os pterossauros e aves eram os vertebrados representativos e os mamíferos evoluíam para sua grande radiação adaptativa no início da próxima Era. O período culmina com uma extinção em massa ocorrida na transição Cretáceo/Paleógeno. Esta extinção deve ter sido acelerada, entre outros fatores, pela queda de um asteroide, cujo impacto provocou uma cratera de $180 \mathrm{~km}$. Em seguida ao choque desse corpo celeste com o planeta, deve ter ocorrido uma escuridão global e uma condição de inverno nuclear (acentuado resfriamento global de longa duração, semelhante ao que deveria ocorrer, hipoteticamente, após uma guerra nuclear). Este evento deve ter ocorrido na península de lucatã, no México (Bowler 2009).

O termo latino cretaceus origina-se de creta (giz, barro branco, argila) que significa feito de argila, da natureza da argila; foi referido por Plínio quando este autor comentou que o melhor pão italiano era feito a partir de uma mistura dos grãos de trigo de inverno da Campania (de cor mais avermelhada), com o de Pisa (de cor branca); esta mistura, quando acrescida de greda (creta), tinha seu peso aumentado (Plínio 1906, HN, 18.33).

O nome "Cretáceo" foi empregado, em 1822, pelo geólogo belga Jean-Baptiste d'Omalius d'Halloy (1783-1875). Em seu trabalho, d'Halloy ao descrever os terrenos secundários, classificou-os em cinco grupos, caracterizando o terceiro grupo como uma formação calcária, atribuindo-Ihe o nome de 
"terreno cretáceo" (d'Halloy 1822). O termo foi aplicado para formações sedimentares da França e da Inglaterra, conhecidas como Creta. O período é representado por sedimentos volumosos distribuídos por todos os continentes (Stokes 1969). Posteriormente, o termo cretáceo apareceu em 1832, no trabalho "A Geological Manual", do geólogo britânico Henry Thomas De La Beche (1796-1855). Nessa obra, o termo foi definido como "um grupo de rochas caracterizadas por calcário em sua porção superior e areias e arenitos, na inferior" (La Beche 1832).

\subsection{2. Éon Fanerozoico: Cenozoica, a Era da Vida Recente}

\subsubsection{CENOZOICA}

Era geológica do éon Fanerozoico que sucedeu a era Mesozoica, tendo-se iniciado há cerca de $66 \mathrm{Ma}$. Nesta Era incluem-se os períodos Paleógeno, Neógeno (em tabelas mais antigas, estes dois períodos eram incluídos em um único, conhecido como Terciário ${ }^{15}$ ), e o Quaternário. A IUGS (International Union of Geological Sciences) tem excluído desde 1989, nas escalas de tempo geológico, o termo Terciário e mantido formalmente o Quaternário. Os autores que se opõem à manutenção desses termos alegam que são relíquias de um sistema que existia desde o século XVIII e que incluía o Primário e o Secundário, termos desusados há muito tempo. Outro argumento para se abandonar o termo Terciário relaciona-se ao fato de que esse período abrange quase toda a Era Cenozoica, sendo, portanto, redundante com quase toda essa era. Entretanto, é importante ressaltar que muitos autores ainda defendem a manutenção do Terciário como um período da Era Cenozoica (Knox et al. 2012). Quanto ao Quaternário, a IUGS decidiu mantê-lo como um período da Era Cenozoica e indicar o seu início há $2.58 \mathrm{Ma}$, quando os estratos rochosos mostraram evidências de uma grande expansão de camadas de gelo sobre as regiões continentais do norte, com mudanças acentuadas nas condições climáticas e das águas oceânicas (Belknap 2020).

15. O Terciário correspondia a um período da era Cenozoica, que incluía o Paleógeno e o Neógeno e iniciou-se há cerca de $66 \mathrm{Ma}$, tendo terminado há, aproximadamente, 2,6 Ma. Constituía-se das épocas do Paleoceno, Eoceno, Oligoceno, Mioceno e Plioceno. Embora seja ainda utilizado informalmente, não faz parte do quadro estratigráfico Internacional. O termo "terciário" foi proposto pelo geólogo italiano Giovanni Arduino (1714-1795), no século XVIII. Ao estudar a geologia das regiões setentrionais da Itália, este autor elaborou uma classificação dos terrenos montanhosos, numa sequência cronológica, em três ordens, do mais antigo para o mais recente. A primeira, a mais profunda, foi denominada "primária"; a segunda, que sucede a anterior e é formada pelas grandes montanhas, pelos montes e as colinas, foi chamada "secundária" e, a terceira, acima da secundária e constituída somente pelos pequenos montes e colinas, foi chamada de "terciária". Em sua classificação, Arduino acrescentou uma ordem mais recente a que denominou "Quarto Ordini", caracterizada por depósitos aluviais e estuarinos dispostos subjacentemente a vales fluviais ou planícies (Arduino 1760). O termo Terciário origina-se do L. tertiarius, que contém um terço; de um terço; de tertius, terceiro. Em seu livro Principles of Geology, Charles Lyell propôs uma subdivisão do período Terciário, fundamentando-se nos resultados comparativos dos fósseis presentes nos estratos analisados e, também, atribuindo nomes aos períodos em que esses fósseis eram encontrados (Lyell 1833). Segundo este critério, os terrenos rochosos são subdivididos levando-se em conta, nessas rochas, a porcentagem de moluscos fósseis comparada à de moluscos atualmente viventes. Os elementos de composição dos termos designativos dessas épocas: paleo, eo, oligo, mio, plio, pleisto fundamentaram-se nesses resultados. Com base na subdivisão proposta por Lyell (que incluía somente três dessas épocas: eoceno, mioceno e plioceno), as épocas dos períodos da Era Cenozoica com as respectivas porcentagens comparativas de moluscos estão indicadas a seguir: Pleistoceno 90 a 100\% das espécies atuais; Plioceno - 50 a $90 \%$ das espécies atuais; Mioceno - 20 a $40 \%$ das espécies atuais; Oligoceno - 10 a $15 \%$ das espécies atuais; Eoceno - 1 a $5 \%$ das espécies atuais; Paleoceno - 0\% das espécies atuais (Stokes 1969).

Na era Cenozoica, os continentes moveramse para as posições em que são encontrados atualmente e a evolução das plantas e dos animais gerou a diversidade que podemos observar nos dias de hoje (Berggren 2019). Conhecida como a Era dos mamíferos, essa unidade do tempo geológico poderia ser igualmente designada como a idade das aves, ou dos insetos, ou ainda, das angiospermas.

O termo cenozoico foi proposto em 1840 pelo geólogo inglês John Phillips (1800-1874). Este autor ao escrever seu artigo "Paleozoic Series", na Penny Cyclopedia, utilizou o termo "kainozoic". Segundo Phillips, "podemos aplicar os termos Paleozoico, Mesozoico e Cenozoico (kainozoic), e outros mais, aos vários sistemas ou combinações de formas orgânicas correspondentes, que podem ser claramente identificáveis na crosta estratificada do planeta" (Phillips 1840). Em seu trabalho de 1841, Phillips redigiu o termo "cainozoic" para designar esse sistema, quando propôs uma classificação dos sistemas de vida orgânica, incluindo três estratos com aquele caracterizado em seu 
trabalho de 1840. Os três estratos são: o Paleozoico; o Mesozoico e o Cenozoico. Este autor indicou a relação do termo com suas respectivas raízes originadas do grego: zôion, ser vivo, animal, vida e kainós, recente, novo (Phillips 1841).

\subsubsection{PALEÓGENO}

Sistema do erátema Cenozoico que inclui as séries Paleoceno, Eoceno e Oligoceno. Período da era Cenozoica que teve início há cerca de 66 Ma e término há uns $23 \mathrm{Ma}$.

Esse período, informalmente conhecido por Terciário Inferior, caracteriza-se geologicamente pelo movimento de deriva dos continentes, cada vez mais se aproximando de suas posições atuais, uma vez que a Gondwana continuava a apresentar separação entre suas partes fragmentadas. Tanto o oceano Atlântico Sul quanto o Atlântico Norte tiveram continuamente suas superfícies ampliadas devido aos movimentos continentais. No final da era Mesozoica, as condições climáticas foram quentes e úmidas, porém no Paleógeno observou-se uma tendência ao clima frio e seco intercalado com períodos climáticos mais quentes (Kindersley 2009).

As plantas que sobreviveram à extinção Cretáceo/Paleógeno sofreram diversificação e observou-se uma coevolução entre plantas angiospermas e alguns grupos de insetos e de vertebrados (Kindersley 2009). Houve um período de mais de 2 Ma para que os ecossistemas terrestres pudessem se recuperar da extinção ocorrida na transição das Eras Mesozoica/Cenozoica. No entanto, os mamíferos e as aves primitivos iniciavam rapidamente sua diversificação (Paselk 2012).

O termo paleógeno (palaeogen) foi introduzido na literatura geológica pelo geólogo e mineralogista alemão Carl Friedrich Naumann (1797-1873), em 1866. Naumann, em seu trabalho "Lehrbuch der Geognosie", vol. 3, p. 8, citou esse termo (Berggren 1998). Neste trabalho, esse autor mencionou o Neógeno, caracterizado por Moritz Hörnes
(Hörnes 1853), em 1853 (que incluia os limites entre o Eoceno e os estratos terciários mais recentes), e empregou o termo Paleógeno para indicar os limites dos estratos terciários mais recentes e o Eoceno (Naumann 1866, Berggren 1998). O termo paleógeno origina-se do G. palaiós, velho, antigo e gígnomai, nascer, gerar.

\subsubsection{PALEOCENO}

Série do sistema Paleógeno posicionada entre o sistema Cretáceo e a série Eoceno. Época geológica do período Paleógeno que inicia a era Cenozoica, tendo começado há cerca de $66 \mathrm{Ma}$ e terminado há uns $56 \mathrm{Ma}$.

$\mathrm{Na}$ época do Paleoceno, os continentes continuavam seus movimentos. A Eurásia e a América do Norte encontravam-se ligadas, mas os componentes da Gondwana estavam se afastando uns dos outros. No início dessa época, o clima era frio, mas logo em seguida, tornou-se mais quente do que o de hoje. No ambiente terrestre, as condições climáticas propiciaram o surgimento dos primeiros cactos e palmeiras e, no final dessa época, selvas e florestas distribuíam-se por grande parte do globo (Strauss 2017). Entre os vertebrados, os mamíferos iniciavam sua radiação massiva que, no final desta época culminou com a substituição de formas arcaicas por mais modernas nos continentes setentrionais. Em todos os continentes onde foram estudados, os mamíferos do Paleoceno mostraram marcantes diferenças em relação aos mamíferos do final do período Cretáceo. Entre os representantes das ordens modernas que surgiram nessa época, incluem-se: carnívoros, edentados, macroscelídeos (musaranhos elefantes) e lipotiflos (insetívoros típicos) (Hooker 2005). As aves também se diversificavam e, algumas possíveis predadoras, tais como Gastornis (Diatryma), que, no final dessa época, atingiram de 2 a $2.5 \mathrm{~m}$ de altura. Embora os dinossauros estivessem extintos, os répteis do Paleoceno continuaram sua evolução com os crocodilos, as serpentes e o os quelônios (Strauss 2017). 
O termo Paleoceno (paléocène) foi cunhado pelo geólogo e botânico francês Wilhelm Philippe Schimper (1808-1880). Este autor utilizou esse termo em seu trabalho "Traité de Paleontologie Vegetal", de 1874. Definiu-o como um período correspondente à transição do Cretáceo Superior ao Terciário Inferior (Schimper 1874). Ao comparar a flora cretácea com a flora desse período, Schimper ressaltou que, na flora cretácea ainda havia um predomínio de vegetais do hemisfério sul, ao passo que a flora paleocênica já mostrava uma tendência à diferenciação de tipos vegetais que, posteriormente, deveriam predominar no hemisfério norte (Schimper 1874). O termo paleoceno origina-se do $G$. palaiós, antigo, velho e kainós, novo, recente; seu significado literal é "antigo recente".

\subsubsection{EOCENO}

Série do sistema geológico Paleógeno localizada acima do Paleoceno e abaixo do Oligoceno. Época geológica do período Paleógeno que teve início há cerca de $56 \mathrm{Ma}$ e término há uns $33.9 \mathrm{Ma}$.

Ao longo da época do Eoceno, os continentes movimentavam-se em direção às suas posições atuais. Nesta época, os climas propiciaram uma distribuição mais ampla de florestas com extensões limitadas de pradarias (Rafferty 2013b). No Eoceno devem ter ocorrido as mais altas temperaturas da Era Cenozoica, verificando-se um aumento da diversidade de plantas do Eoceno Inferior para o Médio, o que sugeriu a ocorrência de um clima tropical mais úmido (Jaramillo 2002).

Nesta época, os mamíferos continuaram sua diversificação, com o predomínio de vários grupos arcaicos e o surgimento dos grupos ancestrais dos mamíferos modernos e dos cetáceos no ambiente marinho. Alguns grupos de aves modernas, tais como os das águias, pelicanos e abutres, juntamente com as extintas diatrimiformes, também estavam presentes (Kazlev 2002b). O final dessa época, na transição Eoceno/Oligoceno, foi marcado por um evento de extinção ocasionado, possivelmente, por variações de temperatura. Este evento foi o mais acentuado do Cenozoico e afetou, fundamentalmente a fauna de invertebrados marinhos (Ivany et al. 2000).

O termo Eoceno foi introduzido na literatura científica na obra "Principles of Geology" de Charles Lyell, em 1833. Em 1831, no entanto, o polímata inglês William Whewell (17941866) já havia criado esse termo em carta que escreveu a Lyell, sugerindo a terminação kainós para os períodos que Lyell estava descrevendo. Whewell, além disso, ressaltou que o termo eoceno se ajustava melhor a um dos períodos descritos por Lyell (Todhunter 1876), que, em razão disso, empregou o termo "eoceno" do G. eos, aurora e kainós, recente, aceitando a sugestão de Whewell. Lyell justificou a inclusão do termo pelo fato de ter observado nos estratos correspondentes desse período, uma porcentagem bastante reduzida de espécies viventes, o que indicava uma evolução dessas espécies, ainda em fase inicial (Lyell 1833). Portanto, o termo Eoceno pode ser entendido em seu sentido literal como a "aurora, o alvorecer do recente, do moderno".

\subsubsection{OLIGOCENO}

Série do sistema geológico Paleógeno localizada acima do Eoceno e abaixo do Mioceno. Época geológica do período Paleógeno que teve início há cerca de 33.9 Ma e término há uns $23 \mathrm{Ma}$.

No início desta época, pôde-se constatar uma expansão das camadas de gelo da Antártida, que ocasionou a redução nos níveis dos mares. Embora outras explicações tenham sido dadas para o resfriamento que ocasionou essa expansão, as mais prováveis são atribuídas ao declínio dos níveis de $\mathrm{CO}_{2}$ atmosférico acompanhado de mudanças nos padrões de circulação de correntes marinhas. Esses efeitos de temperatura nas águas oceânicas implicaram em mudanças, não somente nos climas marinhos, mas também 
nos continentais. No final dessa época as condições climáticas propiciaram um aumento das áreas de pradarias e uma redução das áreas de regiões florestais, estas mais favorecidas em regiões mais meridionais. 0 clima influenciou favoravelmente a ascensão de mamíferos dos grupos dos roedores e de ungulados. Nesta época surgiram mamíferos marinhos, entre os quais, cetáceos e focas (David \& Gautam 2021).

O termo oligoceno foi criado pelo paleontólogo alemão Heinrich Ernst Von Beyrich (1815-1896), em 1854. Esse termo compõe-se do G. oligos, escasso, pouco, em pequeno número e kainós, recente, novo; portanto, em seu significado literal, "pouco recente". Em sua obra, abordando formações Terciárias, von Beyrich empregou o termo oligoceno como um período que se localizava entre os períodos Eoceno, mais antigo, e o Mioceno, mais recente (Beyrich 1854). Essa denominação deveu-se ao fato de os estratos desse período, em particular os do norte da Alemanha, apresentarem quantidade reduzida de fósseis modernos.

\subsubsection{NEÓGENO}

Sistema geológico do erátema Cenozoico incluindo as séries Mioceno e Plioceno. Período da era Cenozoica que se iniciou há cerca de $23 \mathrm{Ma}$ e terminou há uns $2.58 \mathrm{Ma}$.

Neste período, os continentes, em seus movimentos, encontravam-se bem próximos de suas posições atuais; formaram-se o istmo de Panamá e as cadeias montanhosas dos Alpes e do Himalaia. No início do Plioceno, o clima foi quente, mas logo tornou-se frio, propiciando a ocorrência de uma idade glacial no final do período. A vegetação do Neógeno apresentou gradativamente uma aparência semelhante à flora moderna. A fauna marinha de invertebrados assemelhava-se à do Paleógeno. Nos mares, encontravam-se formas gigantes de tubarões e surgiram linhagens modernas de baleias. No ambiente terrestre, as mudanças de condições climáticas possibilitaram o aparecimento de novos grupos de mamíferos, bem como a extinção de grupos mais antigos (Kindersley 2009).

O termo Neógeno foi proposto em 1853 pelo paleontólogo austríaco Moritz Hörnes (18151868). Em seu trabalho, Hörnes aplica o termo para um sistema que incluía os limites entre o Eoceno e os estratos terciários mais recentes. Em seus estudos da fauna de moluscos, observou uma diferença notável entre a fauna dos depósitos eocênicos e os do Mioceno e Plioceno, sentindo-se motivado a agrupar estes dois depósitos sob o nome de Neógeno (do G. néos, novo, recente e gígnomai, nascer, gerar), a fim de diferenciálo claramente do Eoceno (Hörnes 1853).

\subsubsection{MIOCENO}

Série do sistema geológico Neógeno localizada acima do Oligoceno e abaixo do Plioceno. Época geológica do período Neógeno que teve início há cerca de $23 \mathrm{Ma}$ e término há uns $5.33 \mathrm{Ma}$.

Nesta época do período Neógeno, ocorreram ligeiras mudanças na posição dos continentes, que continuavam a se deslocar em direção às suas posições atuais. O clima foi globalmente mais quente do que os das épocas anterior (Oligoceno) e posterior (Plioceno) (Smith et al. 2011a). No início dessa época, ocorreu uma transgressão marinha na costa ocidental da América do Sul (Macharé et al. 1988).

No Mioceno, com o grande desenvolvimento de pradarias, houve predomínio de gramíneas. Entre os mamíferos, os artiodáctilos tornaram-se muito diversificados, porém muitas espécies de perissodáctilos, sobretudo os cavalos, caminharam para uma extinção no final dessa época. Os representantes do gênero Equus, no entanto, sobreviveram (Kindersley 2009). Um aspecto importante na evolução dos primatas foi o surgimento dos driopitecíneos, um grupo de hominídeos que, provavelmente, encontra-se na linhagem da 
ancestralidade dos macacos antropomorfos e dos humanos (Rafferty 2018).

O termo mioceno (do G. méiōn, menor e kainós, recente) foi proposto por Charles Lyell em 1833. Em seu livro "Principles of Geology", este geólogo denominou Mioceno a uma época do Terciário. Lyell, ao explicar a sua etimologia, procurou justificá-la em razão de ter observado nas formações deste período, uma menor quantidade de conchas fósseis de espécies recentes (cerca de 17\%), sendo as restantes (aproximadamente 83\%) de espécies extintas ou fósseis (Lyell, 1833). Entretanto, esse termo apareceu na carta de William Whewell, endereçada a Lyell, em 1831. Nesta carta, Whewell sugeriu para os quatro termos propostos por Lyell, as seguintes denominações: 1 . aceno; 2. eoceno; 3. mioceno; 4. plioceno (Todhunter 1876).

\subsubsection{PLIOCENO}

Série do sistema geológico Neógeno localizada acima do Mioceno e abaixo do Pleistoceno. Época geológica do período Neógeno que teve início há cerca de $5.33 \mathrm{Ma}$ e término há uns $2.58 \mathrm{Ma}$.

No Plioceno, os continentes continuavam a deslocar-se em direção às suas posições atuais. O aparecimento do istmo de Panamá entre a América do Sul e a do Norte possibilitou a migração de plantas e animais para outras regiões. Nessa época, o clima, que até então se apresentava mais quente, começou a esfriar, o que possibilitou uma mudança na vegetação, com pradarias e savanas distribuindo-se na maioria dos continentes. O final dessa época foi marcado por um período de resfriamento geral com grandes camadas de gelo acumuladas na região da Antártida, que se apresentava mais fria do que atualmente (Smith et al. 2011b).

A diversificação de mamíferos perissodáctilos e artiodáctilos que já vinha ocorrendo na época imediatamente anterior, teve continuidade no Plioceno, uma vez que as pradarias e as savanas distribuíam-se na maioria dos continentes (Smith et al. 2011b).
Observou-se uma diversificação de aves e de vários grupos de mamíferos, incluindo-se os herbívoros pastadores, os pequenos carnívoros e os pequenos roedores fossórios. Entre os primatas, destaca-se o surgimento dos australopitecíneos (Kindersley 2009).

O termo Plioceno foi usado pela primeira vez por William Whewell em sua carta de 1831, endereçada a Charles Lyell. Nesta carta, Whewell sugeriu o termo "Plioceno" para o mais recente dos períodos estudados por Lyell (Todhunter 1876). Lyell aceitou a sugestão e incluiu o termo em seu livro Principles of Geology, de 1833. Este autor, analisando os fósseis de testáceos do período, verificou que a maioria deles pertencia a espécies recentes, aplicando a esta época o nome "Plioceno", que se origina do G. pleíōn, mais, maior e kainós, recente (Lyell 1833).

\subsubsection{QUATERNÁRIO}

Sistema do erátema Cenozoico constituído das séries pleistocênica e holocênica. Período da era Cenozoica que se iniciou há cerca de $2.58 \mathrm{Ma}$ e dura até os nossos dias.

O período Quaternário caracteriza-se por relativamente poucas mudanças na configuração dos continentes devido à movimentação das placas tectônicas (Belknap 2020). Neste período houve uma série de 50 ciclos climáticos glaciais-interglaciais. Nas duas épocas em que o Quaternário é dividido, observou-se no Pleistoceno, a primeira delas, longos momentos de glaciações intercalados por interglaciais mais curtos. A época subsequente, o Holoceno ou Recente, iniciada há cerca de 11700 anos (0.0117 Ma), é caracterizada por um momento interglacial (Elias 2013). Foram identificados quatro momentos de glaciação na América do Norte e cinco, no norte europeu e nos Alpes. Mudanças rápidas do clima e do nível dos mares ocorridas entre e, em alguns casos, durante as glaciações, provocaram variações ambientais em todo o planeta e, consequentemente, alterações na flora e na fauna, em curtos períodos de tempo. A 
maioria dos pesquisadores acredita que uma substituição do ambiente de florestas para o de savanas mais secas, em regiões africanas, deve ter conduzido a pressões evolutivas que favoreceram a ocorrência de várias características adaptativas nas linhagens que conduziram ao surgimento dos humanos atuais (Homo sapiens) (Belknap 2020).

O sistema quaternário foi descrito por Giovanni Arduino em 1760, quando estudava a geologia de regiões do norte da Itália. Ao classificar as montanhas dessas regiões, Arduino referiu-se a três ordens e, ainda acrescentou mais uma, denominando-a 'quarta ordem', na qual incluiu toda a planície de aluviões e depósitos de materiais conduzidos dos montes pelas águas fluviais (Arduino 1760).

O termo 'quaternário' foi proposto pelo geólogo francês Jules Pierre Desnoyers (18001887), em 1829. Em seu trabalho, Desnoyers caracterizou os depósitos marinhos mais recentes do que os do Terciário da bacia do rio Sena, como uma formação geológica distinta a que denominou depósitos 'Quaternários'. No entanto, em seguida à sua exposição, esse autor alegando que os depósitos quaternários não eram claramente distintos dos terciários da bacia do Sena, desconsiderou o termo anteriormente proposto (quaternário) (Desnoyers 1829). O termo quaternário origina-se do $\mathrm{L}$. quaternarius, que tem quatro pés; de quaterni, que são em número de quatro).

\subsubsection{PLEISTOCENO}

Série do sistema geológico Quaternário localizada acima do Plioceno e abaixo do Holoceno. Época geológica do período Quaternário que teve início há cerca de 2.58 Ma e término há uns 11700 anos (0.0117 Ma).

Com os continentes praticamente em suas posições atuais, esta época do Quaternário foi marcada por alguns períodos de glaciações maiores e outras menores, separados por interglaciais em que camadas extensivas de gelo formaram-se repetidamente nos continentes. Tais eventos fizeram com que essa época fosse denominada informalmente de "A Grande Idade do Gelo" (Johnson 2018). As mudanças climáticas severas ocorridas no Pleistoceno tiveram influências marcantes na flora e na fauna. Os organismos, sobretudo os de altas latitudes, procuraram refúgios em mais baixas latitudes. Regiões de altas latitudes que não foram atingidas pelos glaciares também serviram como refúgios. Os insetos, muitos grupos de mamíferos e de outros vertebrados deslocaram-se para regiões de climas mais quentes. Do mesmo modo, as plantas de regiões mais frias buscaram refúgios em regiões de climas mais amenos. O registro paleontológico do quaternário mostra que essas mudanças ambientais geraram respostas de movimentos de determinadas espécies e não de comunidades de organismos (Elias 2013). Tanto no ambiente marinho como no terrestre, a fauna pleistocênica pode ser considerada moderna. Um evento de extrema importância nessa época do período Quaternário foi a evolução de características anatômicas dos humanos modernos. Entre elas, distinguem-se: caixa craniana maior, arcadas superciliares menores, queixo mais proeminente e dentes menores (Kindersley 2009). Essas características incluem-se entre as principais que possibilitaram o surgimento do Homo sapiens, com datação aproximada de 200 mil anos (Eriksson et al. 2012), embora mais recentemente, novas descobertas tenham recuado esta data de origem para cerca de 400 mil anos atrás (Hublin et al. 2017).

O termo 'pleistoceno' foi cunhado por Charles Lyell em 1839. Com o objetivo de distinguir os termos então designativos dos períodos 'Plioceno mais antigo', do 'Plioceno mais recente', Lyell alegou que esses termos eram muito longos. Com o propósito de torná-los mais curtos e mais cômodos, propôs a atribuição do nome Plioceno para o mais antigo e Pleistoceno para o mais recente. Este termo compõe-se do G. pleîstos, o mais e kainós, novo, recente. A fim de caracterizar 
esta época, Lyell observou que, em estratos da Sicília, a fauna de moluscos correspondia a mais de $70 \%$ da fauna que se encontra presente atualmente. Este autor notou que no Pleistoceno o registro fóssil indicava um número maior de representantes atuais do que na época anterior, o Plioceno, que ele supunha ser, até então, a mais recente; daí, usar o termo pleîstos, "o mais numeroso", para indicá-la (Lyell 1839).

\subsubsection{HOLOCENO}

Época geológica do período Quaternário incluindo os últimos 11700 anos (0.0117 Ma), desde o final do Pleistoceno até o presente. Frequentemente é também referida como Recente.

Essa época iniciou-se logo após o último período glacial, caracterizando-se como um período relativamente quente, interglacial. Há quem o denomine de "Antropogênico" ou "Idade dos Humanos", embora Homo sapiens tenha evoluído e se dispersado pelo planeta bem antes do início dessa época (Smith \& Waggoner 2011).

As atividades humanas durante o Holoceno têm modificado o ambiente acarretando extinções de grandes organismos e espécies, particularmente em ilhas oceânicas; essas atividades respondem também pelo aumento da heterogeneidade ambiental no planeta e, algumas delas, incluem: alterações de topografias; introdução de animais domésticos com a eliminação dos selvagens, em certas áreas; alteração de ciclos hídricos; mudanças de padrões de temperatura; produção de novos compostos químicos tóxicos de difícil decomposição (Lugo et al. 2018).

O termo 'Holoceno' foi proposto em 18671869, pelo paleontólogo francês Paul Gervais (1816-1879). No trabalho de Gervais, da distribuição de mamíferos fósseis nos diferentes estágios terciários que formam o solo da França, o autor propôs a denominação de 'holocenos' a uma época em que todos os depósitos fossilíferos ocorriam concomitantemente com os humanos (Gervais 1850). O termo holoceno tem o significado de "totalmente recente" e foi aplicado com a finalidade de indicar que, nessa época geológica, a fauna é totalmente nova; origina-se do G. hólos, total, completo e kainós, novo, recente, e refere-se à porcentagem de organismos viventes encontrados como fósseis (o termo foi aplicado "aos depósitos pós-diluviais correspondendo ao período pós-glacial") (Gibbard \& van Kolfschoten 2004).

\section{CONSIDERAÇÕES FINAIS}

Inúmeros termos de origens grega e latina vêm contribuindo, durante alguns séculos, para o enriquecimento do vocabulário dos vários ramos das Ciências, incluindo-se as geológicas e paleontológicas. A partir de alguns elementos de composição, de prefixos e de sufixos, muitos nomes novos puderam ser elaborados nos vários campos dessas ciências.

A maioria desses nomes foi criada no século $\mathrm{XIX}$, pois as unidades principais da coluna geológica padrão tiveram esses termos propostos e aceitos, em geral, entre 1822 e 1887, aumentando assim, o acervo da terminologia geológica e paleontológica a partir desse século.

Segundo o International Stratigraphic Guide, os nomes das unidades geocronológicas (Éons, Eras, Períodos e Épocas) recebem o mesmo nome das unidades cronoestratigráficas correspondentes (Eonótema, Erátemas, Sistemas e Séries). Esses nomes, que foram atribuídos no início da história da Estratigrafia, têm origens diversas, pois alguns são cronológicos (Terciário, Quaternário); outros são litológicos (Carbonífero, Cretáceo) e, ainda outros, são geográficos (Devoniano, Permiano) (Murphy \& Salvador 1999).

Utilizando-se um critério onomatológico, podemos constatar que os nomes das unidades geocronológicas e termos associados, atribuídos pelos diversos autores 
ao longo da história da Geologia, podem ser

caracterizados como neoclássicos

(Proterozoico, Fanerozoico, Cenozoico,

Paleoceno e Oligoceno); geográficos

(Cambriano, Devoniano, Jurássico);

descritivos (Cretáceo, Carbonífero);

etnônimos (Siluriano, Ordoviciano), ou seja, aqueles associados a nomes de povos antigos das regiões estudadas pelos geólogos e, ainda, os mitológicos (Hadeano, Jápeto). Estes últimos, que também poderiam ser incluídos entre os nomes clássicos.

Os nomes dos períodos e das épocas têm importância na história da Geologia e da Paleontologia, uma vez que contribuem para o conhecimento de seus autores, de seus respectivos trabalhos e em que esses autores se basearam para atribuir tais nomes aos processos, idades e sistemas que foram objeto de seus estudos. Além disso, os nomes propostos são relevantes pelo fato de destacarem aspectos históricos das ciências geológicas e paleontológicas. De fato, a grande maioria deles relaciona-se, fundamentalmente, a uma parte da história da Geologia do século XIX e a momentos da vida de seus autores, nesse período.

Cumpre ressaltar que, de um modo geral, além da informação linguística, um nome pode nos remeter a outros aspectos do conhecimento, relacionados a pessoas, crenças, costumes, agricultura, medicina, localizações geográficas, atividades econômicas e ideológicas de um povo. A compreensão do significado de nomes, tais como siluriano, ordoviciano, cambriano e outros, esclarece nossos conhecimentos a respeito de povos ou tribos antigos, de suas localizações geográficas, de seus costumes e de suas atividades beligerantes.

Concluindo esta apreciação, entendemos que a onomatologia se destaca como um campo do conhecimento de interesse para linguistas e outros estudiosos de ciências humanas, bem como para os das ciências biológicas, da saúde e geológicas. Os termos geológicos e paleontológicos e seus derivados, fundamentalmente originados de línguas clássicas, são relevantes não somente para a terminologia dessas ciências, mas além disso, induzem a várias reflexões envolvidas com um conhecimento mais completo da história dessas áreas, e também com a própria história de um povo e de seu desenvolvimento cultural e étnico.

\section{REFERÊNCIAS}

ALDEN A. 2019. "All About Supercontinents." ThoughtCo, Disponivel em: thoughtco.com/supercontinents-of-the-pastand-future-1441117. Acessado em 23 junho 2021.

ALLABY M. 2009. A Dictionary of Zoology. 3rd ed. Oxford University Press, Oxford, 689p.

ALLABY M. 2013. A Dictionary of Geology and Earth Sciences. 4th ed. Oxford University Press, Oxford, 672p.

AL-RAWI M. 2002. Contribution of Ibn Sina to the development of Earth Sciences. Disponível em:

https://muslimheritage.com/ibn-sinadevelopment-earth-sciences/. Acessado em 17 dezembro 2019.

ARDUINO G. 1760. Due lettere del signore Giovanni Arduino sopra varie sue Osservazioni Naturali. Nuova Raccolta di Opuscoli Scientifici e Filologici, 6: 99-180.

ARIAS C. 2008. Palaeoceanography and biogeography in the Early Jurassic Panthalassa and Tethys oceans. Gondwana Research. 14 (3): 306-315.

BAILLY A. 2000. Dictionnaire grec-français. Hachette, Paris, 2230p.

BARTORELLI A., LEVY P., CARNEIRO C.D.R. 2015. Ulisse Aldrovandi: o criador do termo Geologia. Terrae Didatica, 11(2): 88-93.

BELKNAP D.F. 2020. Quaternary. Geochronology. Encyclopaedia Britannica. Disponível em: https://www.britannica.com/science/Quatern ary. Acessado em 23 fevereiro 2020. 
BERGGREN W.A. 1998. The Cenozoic Era: Lyellian (chrono) stratigraphy and nomenclatural reform at the millennium. In: BLUNDELL, D. J. \& SCOTT, A. C. (eds) Lyell: the Past is the Key to the Present. Geological Society, Special Publications, London, 143: 111-132.

BERGgREN W. A. 2019. Cenozoic Era. Encyclopaedia Britannica. Disponível em: https://www.britannica.com/science/Cenozoi cEra. Acessado em 07 fevereiro 2020.

BEYRICH H.E. 1854. Über die Stellung der hessische Tertiärbildungen. Verhandlungen Köngliche Preussischen Akademie Wissenschaft, 640-666.

BORNEMANN A., NORRIS R.D., FRIEDRICH O. et al. 2008. Isotopic Evidence for Glaciation During the Cretaceous Supergreenhouse. Science, 319 (5860): 189-192.

BOWLER P.J. 2003. Evolution. The History of an Idea. 3rd ed. University of California Press, Berkeley, 496p.

BOWLER P.J. 2009. Mass Extinctions. In: RUSE, M.; TRAVIS, J. (ed.). Evolution. The First Four Billion Years. Harvard University Press, Cambridge, 715-720p.

BRANDÃO J. de S. 1992. Dicionário MíticoEtimológico da Mitologia Grega. v. 2. Vozes, Petrópolis, 559p.

BRONGNIART A. 1829. Tableau des Terrains qui Composent L'écorce Du Globe ou Essai sur La Structure de La Partie Connu de La Terre. F. G. Levrault, Paris, 433p.

CHADWICK G.H. 1930. "Subdivision of geologic time". Bulletin of the Geological Society of America. 41: 47-48.

CHANTRAINE P. 1983. Dictionnaire etymologique de la langue grecque. Histoire des mots. Klincksieck, Paris, 1368p.

CHOO B., ZHU M., ZHAO W. et al. 2015. The largest Silurian vertebrate and its paleoecological implications. Sci Rep 4: 5242, Disponível em: https://doi.org/10.1038/srep05242. Acessado em 25 abril 2020.
CLOUD P. A. 1972. Working Model of the Primitive Earth. Am J Sci, 272 (6): 537-548.

COMMELIN P. 2008. Mitologia grega e romana. Martins Fontes, São Paulo, 433p.

CONYBEARE W.D., PHILLIPS W. 1822.

Outlines of the Geology of England and Wales, with an introductory Compendium of the General Principles of that Science and Comparative views of the Structure of the foreign Countries. William Phillips, George Yard, London, 470p. .

DANA J. D. 1872. Green Mountain Geology. On the Quartzit. American Journal of Science and Arts. 3rd Series, 3(16): 250-257.

DAVID A., GAUTAM A. 2021. Cenozoic Era. Disponível em: https://www.researchgate.net/publication/35 0053477_Cenozoic_Era.. Acessado em 25 junho 2021.

DAVIS J. 2019. The Triassic Period: the rise of the dinosaurs. The Natural History Museum. London. Disponível em: https://www.nhm.ac.uk/discover/the-triassicperiod-the-rise-of-the-dinosaurs.html.

Acessado em 31 janeiro 2020.

DESNOYERS J. 1829. Observations sur um ensemble de depôts marins plus recents que les terrains tertiaires du bassin de la Seine, et constituant une formation géologique distincte; précédées dún aperçu de la nonsimultanéité des bassins tertiaires. Annales des Sciences Naturelles, 16: 171-214.

d'HALLOY, J-B. d'O. 1822. Observations sur un essai de carte géologique de la France, des Pays-Bas, et des contrées voisines. Annales des Mines, 7: 353-376.

DONEV J.M.K.C. et al. 2019. Energy Education - Phanerozoic. Disponível em: https://energyeducation.ca/encyclopedia/Pha nerozoic. Acessado em 19 junho 2021.

DUNHILL A.M., FOSTER, W.J., SCIBERRAS J., TWITCHETT R.J. 2018. Impact of the Late Triassic mass extinction on functional diversity and composition of marine ecosystems. Paleontology, 61(1):133-148. 
DURAND-DELGA M. 2006. Analysed'ouvrage. M. Gayet: Alexandre de Humboldt, Le dernier savant universel. Travaux Du Comité Français D'Histoire de la Géologie (COFRHIGÉO) Troisième Série, t. XX n 11: 207-211.

ELIAS S.A. 2013. The Quaternary. Reference Module in Earth Systems and Environmental Sciences. Disponível em: https://www.sciencedirect.com/science/articl e/pii/B9780124095489053501. Acessado em 26 junho 2021.

EMMONS S.F. 1888. Letter to Persifor Frazer, dated May 25, 1887. In: International Geology Congress, American Committee Reports. Philadelphia, S. 4, A58-A60p.

ERIKSSON A., BETTI L., FRIEND A. et al. 2012.

Late Pleistocene climate change and the global expansion of anatomically modern humans. PNAS, 109 (40) 16089-16094.

GERVAIS P. 1850. Sur la répartition des mammifères fossils entre les different étages tertiaires qui concourent à former le sol de La France. Academie des Sciences et Lettres de Montpellier. Section des Sciences, 1: 399-413.

GIBBARD P., van KOLFSCHOTEN T. 2004. The Pleistocene and Holocene Epochs. In: GRADSTEIN F.M., OGG J. G., SMITH A. (eds.) A Geologic Time Scale 2004. Cambridge University Press, Cambridge.

GLARE P.G.W. (Ed.). 2009. Oxford latin dictionary. Oxford University Press, Oxford, 2126p.

GRADSTEIN F.M., OGG J.G., SMITH A.G. 2004. Chronostratigraphy: linking time and rock. In: GRADSTEIN F M., OGG J. G., SMITH A. G. (eds.). A Geologic Time Scale. Cambridge University Press, Cambridge, 20-46p.

HANSEN T.A., KOCH C.F. 2018. Cretaceous Period. Encyclopaedia Britannica. Disponível em:

https://www.britannica.com/science/Cretace ous-Period. Acessado em 04 março 2020.

HAQ B.U., SCHUTTER S.R. 2008. A Chronology of Paleozoic Sea-level Changes. Science, 322 (5898): 64-68.
HARLAND W.B., GAYER R.A. 1972. The Arctic Caledonides and earlier Oceans. Geological Magazine, 109 ( 4): 289-314.

HARPER D. 2001-2020. Gondwana. Disponível em: https://www.etymonline.com/word/gondwan a. Acessado em 24 agosto 2020.

HARPER D. 2001-2020a. Ordovician. Online Etymology Dictionary. Disponível em: https://www.etymonline.com/word/ordovicia n. Acessado em 01 março 2020.

HARPER D. 2001-2020b. Jurassic. Online Etymology Dictionary. Disponível em: https://www.etymonline.com/word/jurassic. Acessado em 04 março 2020.

HESÍODO. 1914. The Homeric Hymns and Homerica with an English Translation by Hugh G. Evelyn-White. Theogony. Harvard University Press, Cambridge, MA. Disponível em: http://data.perseus.org/citations/urn:cts:gree kLit:tlg0020.tlg001.perseus-grc1:104-138. Acessado em 06 janeiro 2020; 08 janeiro 2020; 01 fevereiro 2020.

HINE R.S. (Ed.). 2008. A Dictionary of Biology. Oxford University Press, Oxford, 717p..

HOLLAND S.M. 2018. Ordovician Period. Encyclopaedia Britannica. Disponivel em https://www. britannica.com/science/Ordovici an-Period. Acessado em 13 janeiro 2020.

HOMERO. 1919. Homer. The Odyssey with an English Translation by A.T. Murray, PH.D. In two volumes. Harvard University Press, Cambridge, MA. Disponível em: http://www.perseus.tufts.edu/hopper/text?d oc=Perseus\%3Atext\%3A1999.01.0135\%3Abo ok\%3D10\%3Acard\%3D503. Acessado em 09 fevereiro 2020.

HOMERO. 1920. Homer. Homeri Opera in five volumes. Oxford University Press, Oxford. Disponível em: https://www.perseus.tufts.edu/hopper/text? doc=Perseus\%3Atext\%3A1999.01.0133\%3Ab ook\%3D1\%3Acard\%3D1. Acessado em 08 janeiro 2020; 31 janeiro 2020; 09 fevereiro 2020. 
HOOKER J.J. 2005. Tertiary to Present: Paleocene. In: SELLEY R., COCKS R., PLIMERT I. R. (eds.). Encyclopedia of Geology. 5. Elsevier, Oxford, 459-465p..

HÖRNES M. 1853. Mittheilung an Professor BRONN gerichtet, Wien. Neues Jahrbuch fur Mineralogie, Geologie, Geognosie und Petrefaktenkunde, 806-810.

HOUAISS A., VILLAR M. de S. 2001. Dicionário Houaiss da língua portuguesa: 1.ed. Objetiva, Rio de Janeiro, 2922p.

HOUAISS A., VILLAR M. de S. 2009. Dicionário Houaiss da língua portuguesa: 1.ed. Objetiva, Rio de Janeiro, 1986p.

HOUSE M.R. 2020. Devonian Period. Encyclopaedia Britannica. Disponível em: https://www.britannica.com/science/Devonia nPeriod. Acessado em 16 janeiro 2020.

HUBLIN J-J., BEM-NCER A., BAILEY S.E et al. 2017. New fossils from Jebel Irhoud, Morocco and the pan-African origin of Homo sapiens. Nature, 546: 289-292.

IUGS - International Union of Geological Sciences. 2017. Tabela Cronoestratigráfica Internacional. IUGS. Disponível em: http://www.stratigraphy.org/ICSchart/Chrono stratChart2017-02PTPortuguese.pdf. Acessado em 30 julho 2021.

IVANY L.C., PATTERSON W.P., LOHMANN K.C. 2000. Cooler winters as a possible cause of mass extinction at the Eocene/Oligocene boundary. Nature, 407:887-890.

JARAMILLO C.A. 2002. Response of Tropical Vegetation to Paleogene Warming. Paleobiology, 28 (2): 222-243.

JOHNSON M.E. 2020. Silurian Period. Encyclopaedia Britannica. Disponível em: https://www.britannica.com/science/SilurianPeriod. Acessado em 14 janeiro 2020.

JOHNSON W.H. 2018. Pleistocene Epoch. Geochronology. Encyclopaedia Britannica. Disponível em: https://www.britannica.com/science/Pleistoc ene-Epoch. 2. Acessado em 24 fevereiro 2020.
KAZLEV M.A. 2002a. The Jurassic. The Jurassic Period of the Mesozoic Era: 200 to 146 million years ago. Disponível em: http://palaeos.com/mesozoic/jurassic/jurassic .html. Acessado em 24 junho 2021.

KAZLEV M.A. 2002b. The Eocene. The Eocene Epoch of the Paleogene Period: 38-54 million years ago. Palaeos. Disponível em: http://palaeos.com/cenozoic/eocene/eocene. html. Acessado em 15 fevereiro 2020.

KINDERSLEY D. (ed.). 2009. Prehistoric. The Definitive Visual History of Life on Earth. DK (Dorling Kindersley), London, 512p.

KLAPPENBACH L. 2020. The Carboniferous Period. Thoughtco, Disponível em: https://www.thoughtco.com/carboniferousperiod-129666. Acessado em 17 março 2020.

KNOX R., GIBBARD J.C., GALE A., POWELL J., RAWSON P., SMITH A., WATERS C., ZALASIEWICZ J. 2012. Tertiary:survival of the fittest?. Disponível em: https://www.geolsoc.org.uk/Geoscientist/Arc hive/August-2010/Tertiary-to-do. Acessado em: 08 agosto 2021.

KOSLA A., LUCAS S.G. (eds.). 2016. Cretaceous Period: Biotic Diversity and Biogeography - An Introduction. New Mexico Museum of Natural History and Science Bulletin 71. Disponívelem: https://www.academia.edu/32500025/CRETA CEOUS_PERIOD_BIOTIC_DIVERSITY_AND_BIO GEOGRAPHY_AN_INTRODUCTION. Acessado em 02 maio 2020.

LA BECHE H.T. de. 1832. A Geological Manual. Carey \& Lea, Philadelphia, 535p.

LAPWORTH C. 1879. On the Tripartite Classification of the Lower Palaeozoic Rocks, Geological Magazine, new series, 6 : 1-15.

LIDDELL H.G., SCOTT R. 1996. A greek-english lexicon. Clarendon Press, Oxford, 2042p..

LOGAN A. 2021. Triassic Period. Geochronology. Encyclopaedia Britannica. Disponível em: https://www.britannica.com/science/TriassicPeriod. Acessado em 23 junho 2021. 
LUCANO L. 1962. The civil war books I-X

(Pharsalia). Heinemann, London. https://archive.org/details/lucancivilwarboo0 Olucauoft/mode/2up. Acessado em 17 março 2020.

LUGO A.E., WINCHELL K.M., CARLO T.A. 2018. Novelty in Ecosystems, In: Encyclopedia of the Antropocene, 3: 259-271.

LYELL C. 1833. Principles of Geology, v. 3. John Murray, London, 570p.

LYELL C. 1839. Nouveaux éléments de géologie. Pitois-Levranet, Paris, 648p.

MACHARÉ J., DEVRIES T., BARRON J., FOURTANIER E. 1988. Oligo-Miocene transgression along the Pacific margin of South America: new paleontological evidence from the Pisco basin (Peru). Géodynamique, 3 (I-2): 25-37.

MACNAUGHTON R., COLE J.M., DALRYMPLE R., BRADDY S.J., BRIGGS D., LUKIE T. 2002.

First steps on land: Arthropod trackways in Cambrian-Ordovician eolian sandstone, southeastern Ontario, Canada. J. Geol., 30: 391-394.

MANGER W.L. 2020. Carboniferous Period. Encyclopaedia Britannica. Disponível em: https://www.britannica.com/science/Carbonif erous-Period. Acessado em 24 janeiro 2020.

MASON R. 1988. Did the lapetus Ocean Really Exist?. Geology, 16(9):823-826.

MATASOVIC R. 2008. Etymological Dictionary of Proto-Celtic. Brill, Leiden, 544p.

McNAMARA K.J. 2008. Earth and Life: Origins of Phanerozoic Diversity. Australian Journal of Earth Sciences, 55 (8): 1023-1036.

MELENDEZ B. 1970. Paleontologia. Tomo I Parte General e Invertebrados. 2a ed. Paraninfo, Madrid, 714p.

MINKOFF E.C. 1983. Evolutionary Biology. Addison-Wesley Publ. Co, Reading, Massachusetts, 627p.

MONROE J., WICANDER R. 2014. The Changing Earth. Exploring Geology and
Evolution. 7th ed. Cengage Learning, Stanford, 712p.

MURCHISON R.I. 1835. On the Silurian System of Rocks. Philosophical Magazine. 3rd series, 7: 46-52.

MURCHISON R.I. 1841. First sketch of some of the principal results of a second geological survey of Russia. Philosophical Magazine and Journal of Science, series 3, 19: 417-422.

MURPHY M., SALVADOR A. 1999.

International Stratigraphic Guide - An Abridged Version. Episodes, 22 (4): 255-271.

NAUMANN C.F. 1866. Lehrbuch der Geognosie, V.3 (second edition): Leipzig, Engelmann, 576p.

O'HARA K. 2018. A Brief History of Geology. Cambridge University Press, Cambridge, 262p.

ONIONS C.T. 1985. The Oxford Dictionary of English Etymology. Clarendon Press, Oxford, $1024 p$.

OVÍDIO. 1892. Ovid. Metamorphoses. Hugo Magnus. Gotha (Germany). Friedr. Andr. Perthes.. Disponível em: http://www.perseus.tufts.edu/hopper/text?d oc=Perseus\%3Atext\%3A1999.02.0029\%3Abo ok\%3D1\%3Acard\%3D1. Acessado em 09 janeiro 2020.

PALMER D. 2009. Evolução, A História da Vida. Larousse, São Paulo, 367p.

PASELK R. 2012. Paleogene. Humboldt State University (HSU). Natural History Museum. Disponível em: https://www2.humboldt.edu/natmus/lifeThro ughTime/Paleogene.web/index.htm.

Acessado em 10 fevereiro 2020.

PHILLIPS J. 1840. "Palæozoic series". Penny Cyclopaedia of the Society for the Diffusion of Useful Knowledge. Charles Knight and Co., London, 17:153-154.

PHILLIPS J. 1841. Figures and Descriptions of the Palæozoic Fossils of Cornwall, Devon, and West Somerset. England, U.K. Longman, Brown, Green, \& Longmans, London, 231p. 
PLATÃO. 1903. Plato. Platonis Opera, ed. John Burnet. Oxford University Press.. Disponível em:

http://www.perseus.tufts.edu/hopper/text?d oc=Perseus\%3Atext\%3A1999.01.0169\%3Atex t\%3DPhaedo\%3Asection\%3D114a. Acessado em 19 novembro 2018.

PLÍNIO. 1906. Naturalis Historia. Karl Friedrich Theodor Mayhoff. Lipsiae. Teubner. Disponível em: http://www.perseus.tufts.edu/hopper/text?d oc=Perseus:text:1999.02.0138. Acessados em 08 janeiro 2019; 05 março 2020.

POWELL C.M., YOUNG G.M. 1995. Are Neoproterozoic glacial deposits preserved on the margins of Laurentia related to the fragmentation of two supercontinents?: Comment and Reply. Geology, 23(11): 10531055.

PTOLOMEU. 2013. La Cosmographie de Claude Ptolemée, Latin manuscript copied around 1411. Bibliothèque Renaissance à Nancy. Disponível em: http://bmnrenaissance.nancy.fr/viewer/show/1236\#pag e/n46/mode/1up. Acessado em 16 dezembro 2018.

RAFFERTY J.P. 2007. Old Red Sandstone. Geology. Encyclopaedia Britannica. Disponível em:

https://www.britannica.com/science/OldRed-Sandstone. Acessado em 29 fevereiro 2020.

RAFFERTY J.P. 2013a. Hadean Eon. Geochronology. Encyclopaedia Britannica. Disponível em: https://www.britannica.com/science/HadeanEon. Acessado em 14 fevereiro 2020.

RAFFERTY J.P. 2013b. Eocene Epoch. Geochronology. Encyclopaedia Britannica. Disponivel em: https://www.britannica.com/science/EoceneEpoch. Acessado em 15 fevereiro 2020.

RAFFERTY J.P. 2018. Miocene Epoch. Geochronology. Encyclopaedia Britannica. Disponível em:
https://www.britannica.com/science/Miocen e-Epoch. Acessado em 18 fevereiro 2020.

RETALLACK G.J. 2017. Ordovician Life on Land and Early Paleozoic Global Change. Disponível em: https://doi.org/10.1017/\$1089332600000693 . Acessado em 21 abril 2020.

ROM (Royal Ontario Museum). 2011. Pikaia gracilens. A very primitive fish-like animal. The Burgess Shale Fossil Galery. Disponível em: https://burgess-shale.rom.on.ca/en/fossilgallery/view-species. php?id=101\&ref=i\&. Acessado em 05 fevereiro 2020.

ROVERE A., STOCCHI P., VACCHI M. 2016. Eustatic and Relative Sea Level Changes.

Current Climate Change Reports, 2 (4): 221231.

RUDWICK M.J.S. 2008. Worlds Before Adam: The Reconstruction of Geohistory in the Age of Reform. The University Chicago Press, Chicago, 614p.

SCHIMPER W.P. 1874. Traité de Paléontologie Végétale. Tome 3eme . J. G. Bailliere. Paris, 912p.

SCOTESE C.R. 2009. Late Proterozoic plate tectonics and palaeogeography: A tale of two supercontinents, Rodinia and Pannotia. Geological Society, London, Special Publications, 326, 67-83.

SEARS J.D. 1925. Geology and Coal Resources of the Gallup-Zuni Basin, New Mexico. Bulletin 767. Washington, Government Printing Office, 88p.

SEDGWICK A. 1838. A synopsis of the English series of stratified rocks inferior to the Old Red Sandstone - with an attempt to determine the successive natural groups and formations. Proceedings of the Geological Society of London, 2 (58): 675-685.

SEDGWICK A., MURCHISON R.I. 1835. On the Silurian and Cambrian Systems, exhibiting the order in which the older sedimentary strata succeed each other in England and Wales. The London and Edinburgh Philosophical Magazine and Journal of Science 7, 483-485. 
SEDGWICK A., MURCHISON R.I. 1840. On the physical structure of Devonshire, and on the subdivisions and geological relations of its older stratified deposits, etc. Transactions of the Geological Society of London. Second series. 5 (II): 633-704.

ŞENGÖR C. 2003. The Large-wavelength Deformations of the Lithosphere: Materials for a history of the evolution of thought from the earliest times to plate tectonics. Geological Society of America Memoir. 196, $347 p$.

SIVIN N. 2019. Shen Kua. Encyclopedia. com. Disponível em: https://www.encyclopedia.com/science/dicti onaries-thesauruses-pictures-and-pressreleases/shen-kua. Acessado em 14 junho 2021.

SMITH D., POLLY D., SPEER B. et al. 2011a.

The Miocene Epoch. Disponível em: https://ucmp.berkeley.edu/tertiary/miocene. php. Acessado em 18 fevereiro 2020.

SMITH D., POLLY D., SPEER B. et al. 2011b.

The Pliocene Epoch. Disponível em: https://ucmp.berkeley.edu/tertiary/pli/aupli.h tml. Acessado em 22 fevereiro 2020.

SMITH D., WAGGONER B.M. 2011. The Holocene Epoch. Disponível em: https://ucmp.berkeley.edu/quaternary/holoc ene.php. Acessado em 27 junho 2021.

STOKES W.L. 1969. Historia de la Tierra. Introduccion a la Geologia Historica. Aguilar Ediciones, Madrid, 575p..

STRAUSS B. 2017. The Paleocene Epoch (65-

56 Million Years Ago). Disponível em: https://www.thoughtco.com/the-paleoceneepoch-1091369. Acessado em 07 março 2020.

STUMP E. 1987. Construction of the Pacific margin of Gondwana during the Pannotios cycle. In: McKENZIE G. D. (ed.). Gondwana Six: Structure, tectonics and geophysics. Geophysical Monograph Series. American geophysical Union Monograph 40: 77-87.
SUESS E. 1885. Das antlitz der Erde (The Face of the Earth). University of California Libraries. California, 532p.

SUESS E. 1888. Das Antlitz der Erde.v.2. F. Tempsky, Wien, 703p.

SUESS E. 1893. Are great ocean depths permanent? Natural Science 2: 180-187.

TÁCITO. 1906. Annales ab excessu divi Augusti. Cornelius Tacitus. Charles Dennis Fisher. Clarendon Press. Oxford. Disponível em:

http://www.perseus.tufts.edu/hopper/text?d oc=Perseus\%3Atext\%3A1999.02.0077\%3Abo ok\%3D12\%3Achapter\%3D33. Acessado em 09 dezembro 2018.

TANG C.M. 2018. Tethys Sea. Ancient Ocean, Mesozoic Era. Encyclopaedia Britannica. Disponível em: https://www. britannica.com/place/TethysSea. Acessado em 03 março 2020.

TANG C.M. 2019. Jurassic Period. Encyclopaedia Britannica. Disponível em: https://www.britannica.com/science/JurassicPeriod. Acessado em 03 fevereiro 2020.

TODHUNTER I. 1876. William Whewell, D.D. An Account of his Writings with Selections from his Literary and Scientific Correspondence. v. 2. MacMillan and Co., London 439p.

UNRUG R. 1997. Rodinia to Gondwana: The Geodynamic Map of Gondwana Supercontinent Assembly. GSA Today, 7(1):16.

VAI G.B., CAVAZZA W. 2006. Ulisse Aldrovandi and the origin of geology and science. Disponivel em: https://www. researchgate.net/publication/27 9407051_Ulisse_Aldrovandi_and_the_origin_ of_geology_and_science. Acessado em 16 junho 2021.

VIRGÍlIO. 1900. Vergil. Bucolics, Aeneid, and Georgics of Vergil. J. B. Greenough. Ginn \& Co. Boston Disponível em: http://www.perseus.tufts.edu/hopper/text?d oc=Perseus\%3Atext\%3A1999.02.0059. 
Acessado em 08 janeiro 2020; 02 fevereiro 2020.

VIRGÍLIO. [s. d.]. P. Vergilivs Maro (70-19 B.C.). Aeneid, Eclogues, Georgicon. The Classics Page. Disponível em: http://www.thelatinlibrary.com/verg.html. Acessado em 19 novembro 2018.

VON ALBERTI F.A. 1834. Beitrag zu einer Monographie des bunten Sandsteins, Muschelkalks und Keupers und die Verbindung dieser Gebilde zu einer Formation. J.G. Cotta'schen Buchhandlung, Stuttgart, 366p.

WALCOTT C.D. 1911. Cambrian Geology and Paleontology. v. 2. Middle Cambrian Annelids. Smithsonian Miscellaneous Collections, 57 (5): 109-145.

WEGENER A. 1920. Die Entstehung der Kontinente und Ozeane, F. Vieweg \& Sohn, Braunschweig. Germany, 172p.

WIGNALL P.B. 2009. Mass Extinctions. In: RUSE M.; TRAVIS J. (ed.). Evolution. The First Four Billion Years. Belknap Press, Cambridge, 715-720p.

WINDLEY B.F. 2014. Proterozoic Eon. Geochronology. Encyclopaedia Britannica. Disponível em: https://www.britannica.com/science/Protero zoic-Eon. Acessado em 26 fevereiro 2020.

WOODFORD A.O. 1970. Geología Histórica. Ediciones Omega, Barcelona, 536p..

YOUNG G.M. 2013. Evolution of Earth's climatic system: Evidence from ice ages, isotopes, and impacts. GSA Today, 23(10). Disponível em: https://www.geosociety.org/gsatoday/archive /23/10/article/i1052-5173-23-10-4.htm.

Acessado em 31 dezembro 2019.

ZITTEL K.A. von. 1901. History of geology and palaentology to the end of the Nineteenth Century. W. Scott, London, 562p. 